\title{
Rate and Extent of Growth of a Model Extremophile, Archaeoglobus fulgidus, Under High Hydrostatic Pressures
}

OPEN ACCESS

Edited by:

Mark Alexander Lever,

ETH Zürich, Switzerland

Reviewed by:

Angeliki Marietou,

Aarhus University, Denmark Aude Picard,

University of Nevada, Las Vegas, United States

*Correspondence: Karyn L. Rogers rogerk5@rpi.edu

${ }^{\dagger}$ Present address: Gina C. Oliver,

Department of Geology, San Bernardino Valley College, San

Bernardino, CA, United States Anaïs Cario,

CNRS, ICMCB, Bordeaux INP, University of Bordeaux, Bordeaux,

France

Specialty section: This article was submitted to Extreme Microbiology, a section of the journal Frontiers in Microbiology

Received: 12 January 2020 Accepted: 27 April 2020

Published: 12 June 2020

Citation:

Oliver GC, Cario A and Rogers KL (2020) Rate and Extent of Growth of a Model Extremophile, Archaeoglobus fulgidus, Under High Hydrostatic Pressures. Front. Microbiol. 11:1023. doi: 10.3389/fmicb.2020.01023

\author{
Gina C. Oliver ${ }^{1 \dagger}$, Anaïs Cario ${ }^{1 \dagger}$ and Karyn L. Rogers ${ }^{1,2 *}$ \\ ${ }^{1}$ Department of Earth and Environmental Sciences, Rensselaer Polytechnic Institute, Troy, NY, United States, ${ }^{2}$ Rensselaer \\ Astrobiology Research and Education Center, Rensselaer Polytechnic Institute, Troy, NY, United States
}

High hydrostatic pressure (HHP) batch cultivation of a model extremophile, Archaeoglobus fulgidus type strain VC-16, was performed to explore how elevated pressures might affect microbial growth and physiology in the deep marine biosphere. Though commonly identified in high-temperature and high-pressure marine environments (up to 2-5 km below sea level, 20-50 MPa pressures), A. fulgidus growth at elevated pressure has not been characterized previously. Here, exponential growth of $A$. fulgidus was observed up to $60 \mathrm{MPa}$ when supported by the heterotrophic metabolism of lactate oxidation coupled to sulfate reduction, and up to $40 \mathrm{MPa}$ for autotrophic $\mathrm{CO}_{2}$ fixation coupled to thiosulfate reduction via $\mathrm{H}_{2}$. Maximum growth rates for this heterotrophic metabolism were observed at $20 \mathrm{MPa}$, suggesting that $A$. fulgidus is a moderate piezophile under these conditions. However, only piezotolerance was observed for autotrophy, as growth rates remained nearly constant from 0.3 to $40 \mathrm{MPa}$. Experiments described below show that $A$. fulgidus continues both heterotrophic sulfate reduction and autotrophic thiosulfate reduction nearly unaffected by increasing pressure up to $30 \mathrm{MPa}$ and $40 \mathrm{MPa}$, respectively. As these pressures encompass a variety of subsurface marine environments, A. fulgidus serves as a model extremophile for exploring the effects of elevated pressure on microbial metabolisms in the deep subsurface. Further, these results exemplify the need for high-pressure cultivation of deep-sea and subsurface microorganisms to better reflect in situ physiological conditions.

Keywords: piezophiles, Archaeoglobus fulgidus, high-pressure microbiology, microbial physiology, deep marine biosphere

\section{INTRODUCTION}

High hydrostatic pressure (HHP) is an inherent characteristic of all deep marine ecosystems (e.g., Jannasch and Taylor, 1984; Oger and Jebbar, 2010; Picard and Daniel, 2013), which are anchored by diverse microbial communities of primary producers and consumers. However, growth physiology under high-pressure conditions for most of the resident species is poorly understood, thus limiting our understanding of how the deep subsurface microbiome cycles mass and energy in its natural 
habitats. HHP microbial cultivation, though first introduced by Zobell and Oppenheimer (1950), has still not been widely adopted, largely due to costs and complexities of developing specialized high-pressure equipment (e.g., Jebbar et al., 2015; McNichol et al., 2016; Cario et al., 2019; Garel et al., 2019). Therefore, most microorganisms recovered from the deep biosphere are cultivated at ambient or near ambient pressures (i.e., 0.1-0.3 MPa) using traditional batch cultivation techniques, giving little insight into their in situ physiologies.

In general, studies of microbial responses to high pressure can be divided into those that focus on the potentially deleterious effects of pressure on surface species, and the adaptation mechanisms of piezotolerant and piezophilic organisms. By definition, those species that are negatively impacted by highpressure conditions are categorized as piezosensitive, while piezotolerant species are insensitive to high pressure up to a limit; finally piezophiles grow optimally at elevated pressure and some of these are incapable of growth at ambient pressure (obligate piezophiles; e.g., Jannasch and Taylor, 1984; Kato et al., 2008; Fang et al., 2010). While these categories are traditionally applied at the strain level, the pressure response can vary within a strain as other growth conditions vary (e.g., metabolism, temperature, energy supply; Nogi et al., 1998; Zhao et al., 2015).

For organisms inhabiting surface environments, increasing pressures can disrupt cell division, nucleoid structure, rates of DNA replication, RNA synthesis and protein synthesis (Welch et al., 1993; Abe et al., 1999; Abe and Horikoshi, 2001). Also, pressures outside the optimal range induce the synthesis of stress response proteins and chaperone molecules (Welch et al., 1993; Abe et al., 1999; Abe and Horikoshi, 2001). Effects of high-pressure on biochemical pathways and physiology have been reviewed by Jaenicke (1983). The most commonly observed response to pressure in piezotolerant or piezophilic species is a change in the protein profile, often related to regulation of cytochromes, membrane proteins, DNA recombination and repair enzymes, heat shock proteins and chaperone molecules (e.g., Straube et al., 1990; Holden and Baross, 1993, 1995; Hei and Clark, 1994; Michels et al., 1996; Marteinsson et al., 1997; Abe et al., 1999; Sun and Clark, 2001; Boonyaratanakornkit et al., 2006). Changes in both lipid composition and fluidity have also been attributed to high-pressure conditions (Kaneshiro and Clark, 1995; Abe et al., 1999). Genomic adaptations to high-pressure include elongated intergenic spacer regions, increases in RNA copy number, and elongation of the 16S rRNA helices (Vezzi, 2005; Lauro and Bartlett, 2007; Lauro et al., 2007). High-pressure modifications have also been identified in the transcriptome of piezophiles (Vezzi, 2005; Boonyaratanakornkit et al., 2006), and studies of some hyperthermophilic Archaea (e.g., Thermococcus kodakarensis, Thermococcus barophilus, Pyrococcus yayanosii; Vannier et al., 2015; Michoud and Jebbar, 2016), indicate that the pressure stress response involves a global scale metabolism modification rather than a classical stress response. More generally, a universal adaptation to HHP or a characteristic suite of "high-pressure" genes or proteins has not been identified so far in piezophiles (Jebbar et al., 2015; Zhang et al., 2015; Charlesworth and Burns, 2016).
In addition to these biochemical and molecular studies, several studies focus on how HHP can impact microbial growth (e.g., Zobell and Oppenheimer, 1950; Yayanos et al., 1982; Jannasch et al., 1992; Bartlett, 2002; Takai et al., 2008; Garel et al., 2019). When considering both isolated species and environmental enrichment experiments, Cario et al. (2019) found that initial habitat depth is correlated with a positive growth response to pressure. Furthermore, responses to elevated pressures are generally species- or strain-specific (e.g., Kato et al., 2008; Fang et al., 2010; Jebbar et al., 2015). Among the thermophiles, various responses have been observed, including (i) increases in temperature optima; (ii) increases in temperature maxima; (iii) increases in growth rate; and (iv) increases in metabolic rate (Abe and Horikoshi, 2001; Scoma et al., 2019), although these responses are not uniform across species. In the cases of Methanopyrus kandleri, Pyrococcus abyssi, and P. yayanosii, optimal growth temperatures, maximum growth temperatures, and maximum growth rates all increased with pressures in excess of 0.1 MPa (Erauso et al., 1993; Marteinsson et al., 1997; Takai et al., 2008; Zeng et al., 2009; Birrien et al., 2011). For some thermophiles maximum temperatures increase with pressure, while optimal temperatures remain unchanged (e.g., Marteinsson et al., 1999), and for others growth rate is the primary parameter impacted by increasing pressure (Bernhardt et al., 1987, 1988; Jannasch et al., 1992; Hei and Clark, 1994; Alain et al., 2002; Takai et al., 2009). Metabolic rates, independent of cell growth rates, have also been enhanced by high pressure (Miller et al., 1988).

These studies highlight the variety of microbial response to high pressure, and specifically the lack of predictability with current data. Therefore, realistic models of deep marine microbial ecosystems require more robust characterizations of microbial physiology at conditions that more accurately reflect in situ environments, including elevated pressures. Because microorganisms respond differently to pressure, controlled laboratory growth experiments can be used to isolate specific high-pressure adaptive mechanisms from other environmental parameters. Using well-studied, model organisms to characterize HHP growth can greatly advance our understanding of how microbes grow and transduce energy in subsurface highpressure conditions.

Here a model extremophile, Archaeoglobus fulgidus type strain VC-16, was used to explore the effects of HHP on microbial growth. A. fulgidus is a marine hyperthermophilic sulfatereducing archaeon that has been found in both surface and deep environments (e.g., Stetter et al., 1987; Zellner et al., 1989; Burggraf et al., 1990; Stetter, 1992). A. fulgidus is one of the best described species of this genus (Achenbach-Richter et al., 1987; Klenk et al., 1997), as it was the first hyperthermophilic sulfatereducing archaeon isolated and characterized, and one of the first archaea to have its genome sequenced (Stetter, 1988; Thauer and Kunow, 1995; Klenk et al., 1997; Rabus et al., 2013). A. fulgidus has been shown to grow as both a chemoorganoheterotroph and a chemolithoautotroph and can utilize various organic and inorganic carbon compounds (e.g., lactate, formate, fatty acids, $n$-alkenes, and $n$-alkanes, $\mathrm{CO}_{2}, \mathrm{CO}$ ) and sulfur compounds (i.e., $\mathrm{SO}_{4}^{2-}, \mathrm{SO}_{3}^{2-}$, and $\mathrm{S}_{2} \mathrm{O}_{3}^{2-}$; Stetter et al., 1987; Stetter, 1988, 1992; 
Zellner et al., 1989; Burggraf et al., 1990; Hartzell and Reed, 2006; Khelifi et al., 2010, 2014; Hocking et al., 2014). Even though A. fulgidus was first isolated from a shallow marine hydrothermal system (Stetter et al., 1987), it is a ubiquitous member of subsurface microbial communities. For example, A. fulgidus strains have been isolated from a deep-sea hydrothermal vent (Nakagawa et al., 2005), deep oil reservoirs (Stetter et al., 1993; Beeder et al., 1994; L'Haridon et al., 1995), and deep geothermal wells (Fardeau et al., 2009; Table 1). Also, it has been identified via molecular techniques in various deep-sea vents and shallow terrestrial hot springs (e.g., Takai and Horikoshi, 1999; Nercessian et al., 2003; Schrenk et al., 2003; Table 1). Because sulfate reducing archaea play an important role in the biogeochemical cycling of sulfur and carbon (Hartzell and Reed, 2006; Rabus et al., 2013), it is critical to cultivate organisms such as A. fulgidus at elevated pressures to assess their ability to cycle carbon and sulfur compounds in deep environments as efficiently as they do at surface pressure conditions.

The common occurrence of A. fulgidus in high-pressure subsurface environments suggests that A. fulgidus is at least piezotolerant. Growth up to $35 \mathrm{MPa}$ has been reported for a related strain, A. fulgidus TF2 (Stetter et al., 1993). Furthermore, in Guaymas Basin hydrothermal sediments, where members of the Archaeoglobales have been identified with $16 \mathrm{~S}$

TABLE 1 | Archaeoglobus Isolates.

\begin{tabular}{|c|c|c|c|c|}
\hline $\begin{array}{l}\text { Species, } \\
\text { Strain }\end{array}$ & Environment & Depth & Location & Reference \\
\hline \multicolumn{5}{|l|}{ A. fulgidus } \\
\hline VC-16+ & Shallow vent & $1-10 m$ & Vulcano, Italy & $\begin{array}{l}\text { Stetter et al., } \\
1987\end{array}$ \\
\hline Z & Shallow vent & $1-10 m$ & Vulcano, Italy & $\begin{array}{l}\text { Zellner et al., } \\
1989\end{array}$ \\
\hline NS70-A & Deep-sea vent & $\sim 968 \mathrm{~m}$ & $\begin{array}{l}\text { Iheya North } \\
\text { Fields }\end{array}$ & $\begin{array}{l}\text { Nakagawa } \\
\text { et al., } 2005\end{array}$ \\
\hline TF2 & Oil reservoir & $2-4 \mathrm{~km}$ & North Sea & $\begin{array}{l}\text { Stetter et al., } \\
1993\end{array}$ \\
\hline 7324 & Oil reservoir & $2-4 \mathrm{~km}$ & North Sea & $\begin{array}{l}\text { Beeder et al., } \\
1994\end{array}$ \\
\hline SL5 & Oil reservoir & $1.6 \mathrm{~km}$ & $\begin{array}{l}\text { Paris Basin, } \\
\text { France }\end{array}$ & $\begin{array}{l}\text { L'Haridon et al., } \\
1995\end{array}$ \\
\hline L3 and L4 & $\begin{array}{l}\text { Geothermal } \\
\text { system }\end{array}$ & $1.9 \mathrm{~km}$ & $\begin{array}{l}\text { Paris Basin, } \\
\text { France }\end{array}$ & $\begin{array}{l}\text { Fardeau et al., } \\
2009\end{array}$ \\
\hline \multicolumn{5}{|l|}{ A. profundus } \\
\hline AV18 & Deep-sea vent & $2 \mathrm{~km}$ & $\begin{array}{l}\text { Guaymas } \\
\text { Basin, Mexico }\end{array}$ & $\begin{array}{l}\text { Burggraf et al., } \\
1990\end{array}$ \\
\hline NI85-A & Deep-sea vent & $\sim 968 \mathrm{~m}$ & $\begin{array}{l}\text { Iheya North } \\
\text { Fields }\end{array}$ & $\begin{array}{l}\text { Nakagawa } \\
\text { et al., } 2005\end{array}$ \\
\hline A. veneficus & Deep-sea vent & $3.5 \mathrm{~km}$ & $\begin{array}{l}\text { Mid-Atlantic } \\
\text { Ridge }\end{array}$ & $\begin{array}{l}\text { Huber et al., } \\
1997\end{array}$ \\
\hline A. infectus & Deep-sea vent & $1.4 \mathrm{~km}$ & Izu-Bonin Arc & $\begin{array}{l}\text { Mori et al., } \\
2008\end{array}$ \\
\hline $\begin{array}{l}\text { A. sulfaticallidus } \\
\text { PM70-1 }\end{array}$ & $\begin{array}{l}\text { Black rust } \\
\text { (borehole) }\end{array}$ & $2.65 \mathrm{~km}$ & $\begin{array}{l}\text { Juan de Fuca } \\
\text { Ridge }\end{array}$ & $\begin{array}{l}\text { Steinsbu et al., } \\
2010\end{array}$ \\
\hline $\begin{array}{l}\text { 'A. } \\
\text { lithotrophicus' }\end{array}$ & Oil reservoir & $2-4 \mathrm{~km}$ & North Sea & $\begin{array}{l}\text { Stetter et al., } \\
1993\end{array}$ \\
\hline
\end{tabular}

†Type Stain (DSM 4304). amplicon sequencing (Teske et al., 2002), radiotracer incubation experiments suggested that microbial sulfate reduction is enhanced by HHP (Kallmeyer et al., 2003). Nonetheless, the pressure-dependent growth of A. fulgidus type strain VC-16 remains uncharacterized and the impact that this ubiquitous model hyperthermophile might have on metabolic and biogeochemical networks in high-pressure subsurface environments is unknown. Using a model strain that is metabolically versatile further opens the opportunity to compare heterotrophy to autotrophy within a single species at high pressure, which has yet to be demonstrated. Here the potential for A. fulgidus type strain VC-16 to grow at elevated pressures was investigated at pressures up to $70 \mathrm{MPa}$. Growth rates and cell densities for batch culture growth experiments are reported for both a chemoorganoheterotrophic metabolism coupling lactate oxidation with sulfate reduction, and a chemolithoautotrophic metabolism in which thiosulfate is reduced to $\mathrm{H}_{2} \mathrm{~S}$ with $\mathrm{H}_{2}$.

\section{MATERIALS AND METHODS}

\section{Growth Media Preparation}

Archaeoglobus fulgidus type strain VC-16 (DSM 4304) was obtained from the Deutsche Sammlung von Mikroorganismen und Zellkulturen GmbH (DSMZ, Braunschweig, Germany). Here, chemoorganoheterotrophic growth experiments contained lactate as the electron donor and carbon source coupled to sulfate reduction. The heterotrophic growth medium contained a sea salt base with a composition as follows (per liter): $0.34 \mathrm{~g} \mathrm{KCl}, 15.142 \mathrm{~g} \mathrm{MgSO}_{4} \cdot 7 \mathrm{H}_{2} \mathrm{O}, 2.75 \mathrm{~g} \mathrm{MgCl} \cdot 6 \mathrm{H}_{2} \mathrm{O}, 0.25 \mathrm{~g}$ $\mathrm{NH}_{2} \mathrm{Cl}, 0.056 \mathrm{~g} \mathrm{CaCl}_{2} \cdot 2 \mathrm{H}_{2} \mathrm{O}, 0.0137 \mathrm{~g} \mathrm{~K}_{2} \mathrm{HPO}_{4} \cdot 3 \mathrm{H}_{2} \mathrm{O}, 17.8 \mathrm{~g}$ $\mathrm{NaCl}, 0.0039 \mathrm{~g} \mathrm{Fe}\left(\mathrm{NH}_{4}\right)_{2}\left(\mathrm{SO}_{4}\right) \cdot 6 \mathrm{H}_{2} \mathrm{O}$, and $1 \mathrm{~mL}$ of Wolfe's trace element solution (Hartzell and Reed, 2006). This sea salt base along with $0.1 \mathrm{~mL}$ Resazurin $(0.1 \%$ solution $)$ was autoclaved at $121^{\circ} \mathrm{C}$ for $20 \mathrm{~min}$ and cooled to room temperature. Subsequently, stock solutions of sodium L-lactate $\left(\mathrm{NaC}_{3} \mathrm{H}_{5} \mathrm{O}_{3} ; 2.1 \mathrm{~g} / \mathrm{L}\right.$ final concentration), yeast extract (1 g/L final concentration), and PIPES (piperazine- $N, N^{\prime}$-bis[2-ethanesulfonic acid]; $3.36 \mathrm{~g} / \mathrm{L}$ final concentration) was added by filter sterilization in a biosafety cabinet and the $\mathrm{pH}$ was adjusted to 6.7. The sterile medium was aseptically distributed into sterile Balch tubes $(10 \mathrm{~mL}$ of medium), capped with sterile butyl stoppers and crimped. Prior to inoculation, the headspace above the medium was replaced with $\mathrm{N}_{2}$ by flushing Balch tubes for 15-20 min and a 2.5\% (w/v) $\mathrm{Na}_{2} \mathrm{~S} \cdot 9 \mathrm{H}_{2} \mathrm{O}$ stock solution was added to a final concentration of $1 \mathrm{mM}$ to obtain anoxic conditions (Cario et al., 2016).

Here, chemolithoautotrophic growth was measured for thiosulfate reduction with $\mathrm{H}_{2}$ supporting $\mathrm{CO}_{2}$ fixation (Stetter, 1988; Hartzell and Reed, 2006; Hocking et al., 2014) after A. fulgidus VC-16 was adapted from a heterotrophic metabolism to an autotrophic metabolism (see Supplementary Material for details). The autotrophic growth medium was similar to the heterotrophic medium with the following modifications: $\mathrm{MgSO}_{4} \cdot 7 \mathrm{H}_{2} \mathrm{O}$, sodium L-lactate, and yeast extract were omitted; $\mathrm{MgCl} \cdot 6 \mathrm{H}_{2} \mathrm{O}$ was increased to $6.38 \mathrm{~g} / \mathrm{L}$ to maintain salinity; $\mathrm{CaCl}_{2} \cdot 2 \mathrm{H}_{2} \mathrm{O}$ was increased to $0.14 \mathrm{~g} / \mathrm{L}$; PIPES was replaced 
with $2 \mathrm{~g} / \mathrm{L} \mathrm{NaHCO}_{3}$. To obtain anoxia, the medium was boiled under an $\mathrm{N}_{2}$ atmosphere and the $\mathrm{pH}$ was adjusted to 7.3 to compensate for the decrease in $\mathrm{pH}$ induced by $\mathrm{CO}_{2}$ addition. The anoxic, $\mathrm{pH}$-adjusted medium was transferred to $\mathrm{N}_{2}$-flushed serum bottles, sealed with butyl rubber stoppers and crimp-sealed prior to autoclaving. Following sterilization, the headspace was vacuumed and flushed with a $80 \% \mathrm{H}_{2}: 20 \% \mathrm{CO}_{2}$ gas mixture. Prior to inoculation, $2.5 \%(\mathrm{w} / \mathrm{v}) \mathrm{Na}_{2} \mathrm{~S} \cdot 9 \mathrm{H}_{2} \mathrm{O}$ was added to a final concentration of $1 \mathrm{mM}$ to obtain anoxic conditions (Cario et al., 2016), and subsequently each serum bottle was amended with a sterile, anoxic $2.5 \%(\mathrm{w} / \mathrm{w}) \mathrm{Na}_{2} \mathrm{~S}_{2} \mathrm{O}_{3}$ stock solution to a final concentration of $47 \mathrm{mM}$ (Hocking et al., 2014).

\section{Heterotrophic Ambient Pressure and HHP Batch Cultivation Experiments}

For HHP batch cultivation, triplicate batch culture experiments and a single uninoculated control were conducted at $0.1-70 \mathrm{MPa}$ at $10 \mathrm{MPa}$ increments. For each triplicate, $30 \mathrm{~mL}$ of sterile, anaerobic medium was inoculated with $3 \%(\mathrm{v} / \mathrm{v})$ logarithmic phase $A$. fulgidus cells from three separate precultures to a final cell concentration of $\sim 1.25 \times 10^{7}$ cells $/ \mathrm{mL}$. Inoculated growth medium for each triplicate was transferred aseptically into $5 \mathrm{~mL}$, $\mathrm{N}_{2}$-flushed plastic syringes (BD medical). After transfer, excess $\mathrm{N}_{2}$ gas was expelled from each syringe before the needle was embedded into a silicone stopper to maintain a closed system. The syringes were placed inside pre-heated stainless steel pressure vessels, filled with deionized water, and pressurized using a hydraulic screw pump (High Pressure Equipment Company ${ }^{\odot}$ ) to the desired pressure (Figure 1; Zobell and Oppenheimer, 1950; Yayanos, 2001). Parallel, ambient pressure experiments were carried out in Balch tubes (Balch et al., 1979), or in headspacefree syringes similar to HHP experiments without pressurization (0.1 MPa). Experiments conducted in Balch tubes were amended with a $0.3 \mathrm{MPa} \mathrm{N}_{2}$ headspace following inoculation. All experiments were incubated at $83^{\circ} \mathrm{C}$ for the duration of each experiment. Each HHP batch culture experiment, along with the ambient-pressure controls were subsampled $\sim 11$ times to obtain complete growth curves. Subsamples for cellular enumeration were taken every 2-4 h after inoculation for $36 \mathrm{~h}$ for $0.1-40 \mathrm{MPa}$ experiments and up to $52 \mathrm{~h}$ for 50-70 MPa experiments. Pressure vessels were decompressed at an average rate of $19 \mathrm{MPa} / \mathrm{min}$ and $0.5 \mathrm{~mL}$ subsamples were fixed with $2.5 \%$ (v/v) gludaraldehyde for subsequent enumeration.

Because the static pressure vessels require decompression for subsampling and such decompression can negatively impact microbial growth during high-pressure cultivation (Park and Clark, 2002), a suite of high-pressure experiments tested the effects of multiple decompression-repressurization cycles on growth (Supplementary Figure 1). In order to minimize the effects of decompression cycles four replicates of each experiment (triplicate growth experiments and one uninoculated control) were distributed across four static pressure vessels and subsampling alternated among these. Therefore, a total of twelve $5 \mathrm{~mL}$ syringe cultures, four syringes from each triplicate for each vessel, and four $3 \mathrm{~mL}$ syringes filled with uninoculated medium for negative controls, were prepared for each HHP experiment. To obtain complete growth curves (36-52 h), each vessel was subjected to a maximum of four decompression-repressurization cycles, with at least $6 \mathrm{~h}$ between cycles.

Lastly, A. fulgidus cell recovery after a 52 -h exposure at $70 \mathrm{MPa}$ for the heterotrophic metabolism was tested. Logarithmic-phase A. fulgidus cells were incubated in triplicate at $70 \mathrm{MPa}$ and $83^{\circ} \mathrm{C}$ for $52 \mathrm{~h}$ in a single, heated pressure vessel. Because the effects of decompression on A. fulgidus cells at $70 \mathrm{MPa}$ were unknown, these incubations were also decompressed and repressurized four times at $18,24,36$, and $52 \mathrm{~h}$ after inoculation. Following $52 \mathrm{~h}$ of incubation, a final concentration of $\sim 1.1 \times 10^{7}$ cells/mL was transferred into sterile anaerobic medium in Balch tubes at $0.3 \mathrm{MPa}$ and growth was monitored visually until the

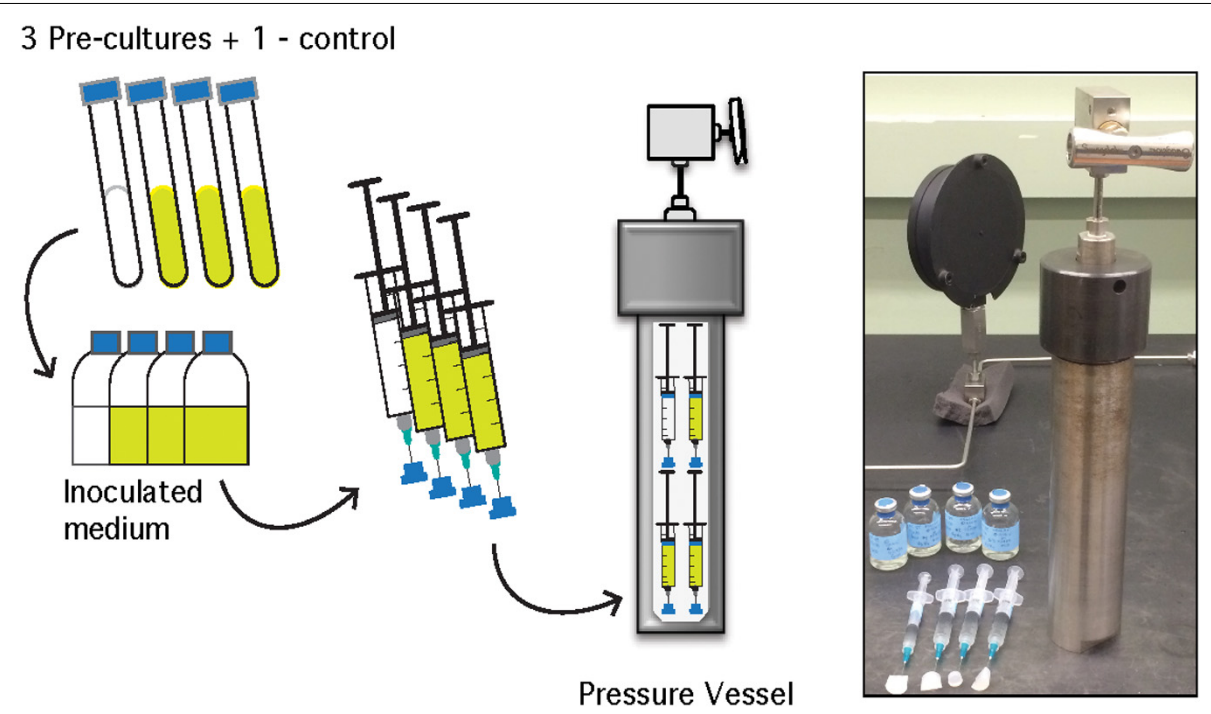

FIGURE 1 | Schematic of A. fulgidus HHP heterotrophic batch culture growth experiments (performed in triplicate with a negative control). See text for details. 
culture became turbid after $64 \mathrm{~h}$ and direct counts of triplicate experiments were taken.

\section{Autotrophic Ambient Pressure and HHP Batch Cultivation Experiments}

Similar to HHP heterotrophic growth experiments, HHP experiments exploring autotrophy were also conducted in syringes contained in static pressure vessels, with replicates distributed to minimize decompression-repressurization cycles. However, because the autotrophic metabolism depends on significant concentrations of dissolved volatiles $\left(\mathrm{H}_{2}, \mathrm{CO}_{2}\right)$, modifications to the standard protocol were necessary. Specifically, all HHP autotrophic experiments were carried out in glass, gas-tight syringes and additional $\mathrm{H}_{2}$ was added prior to pressurization to mitigate gas loss. The detailed experimental protocol is outlined in Figure 2 and described below.

Autotrophic HHP batch cultivation of A. fulgidus was carried out in glass gas-tight syringes (Hamilton, $5 \mathrm{~mL}$ luer slip tip syringes) following methods of Takai et al. (2008) and Tasumi et al. (2015). Clean and dried $5 \mathrm{~mL}$ glass syringes (Hamilton, Reno, NV, United States), chromatography needles, butyl stoppers, Teflon tape, and butyl rubber tape for sealing the needle-syringe connection, were sterilized under UV light for $1 \mathrm{~h}$ in a biosafety cabinet (Figure 2, Step 1). Syringes were assembled to maintain gas-tight conditions during incubation by wrapping the syringe luer slip tip with Teflon, then attaching the needle to the syringe and finally sealing the needle-syringe connection with butyl rubber tape. Syringes and attached needles were then flushed with $\mathrm{N}_{2}$ using an over-pressurized (0.3 MPa) bottle (Figure 2, Step 2). The autotrophic, anaerobic growth medium was prepared in $30 \mathrm{~mL}$ serum bottles (Figure 2, Step 3). Each serum bottle was inoculated with $1.5 \%(\mathrm{v} / \mathrm{v})$ logarithmic phase A. fulgidus cells from three separate precultures to a final cell concentration of $\sim 3 \times 10^{6}$ cells $/ \mathrm{mL}$. The headspace was replaced with a $80 \% \mathrm{H}_{2}: 20 \% \mathrm{CO}_{2}$ gas mixture to $0.3 \mathrm{MPa}$ and left to equilibrate for $\sim 5 \mathrm{~min}$ (Figure 2, Step 4 ). Next, $4 \mathrm{~mL}$ of inoculated and gas-equilibrated medium was transferred into each syringe from a serum bottle (Figure 2, Step 5). Previous experiments containing $3 \mathrm{~mL}$ ultrapure water $(18.2 \mathrm{M} \Omega)$ and $1 \mathrm{~mL} \mathrm{H}_{2}$ in gas-tight glass syringes showed at most a $0.2 \mathrm{~mL} \mathrm{H}_{2}$ loss (by volume) after incubation at $60 \mathrm{MPa}$ and $83^{\circ} \mathrm{C}$ for $150 \mathrm{~h}$. Therefore, $\sim 0.5 \mathrm{~mL}$ of $100 \% \mathrm{H}_{2}$ was added to each syringe to mitigate $\mathrm{H}_{2}$ loss on pressurization (Figure 2, Step 6), thus making these experimental conditions more comparable to experiments carried out in Balch tubes with a $0.3 \mathrm{MPa} 80 \% \mathrm{H}_{2} / 20 \% \mathrm{CO}_{2}$ headspace. Finally, the needles were embedded into butyl rubber stoppers to maintain a closed system. All of the syringes were then placed into pre-heated $83^{\circ} \mathrm{C}$ vessels and pressurized as described in section "Heterotrophic Ambient Pressure and HHP Batch Cultivation Experiments" (Figure 2, Step 7).

Two near-ambient pressure control experiments were conducted in serum bottles. First, the inoculated medium remaining in the serum bottles used to fill the glass syringes was incubated at $83^{\circ} \mathrm{C}$ to monitor growth under optimum conditions. Second, to observe if there was a significant difference in growth

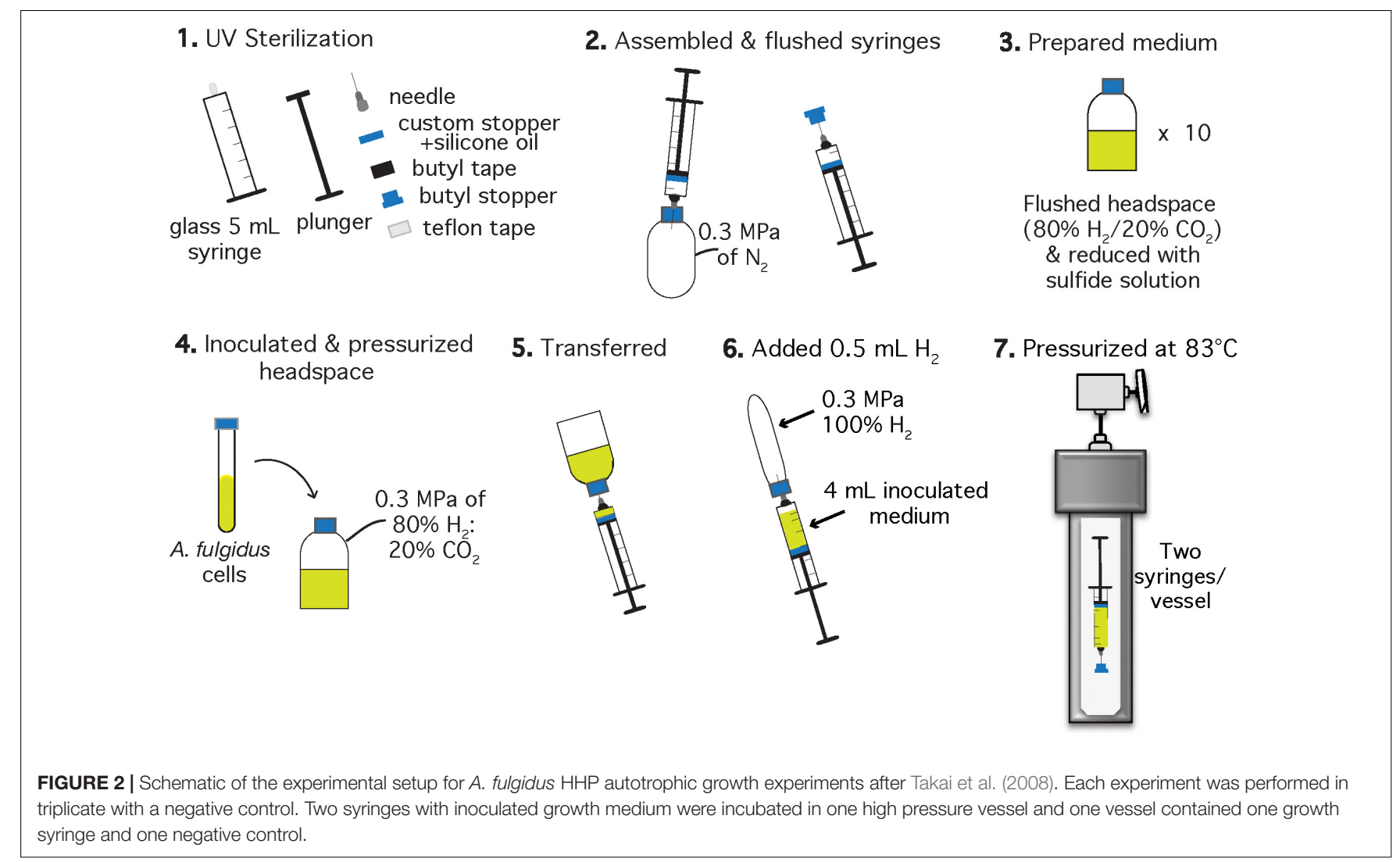


using traditional batch culture techniques versus HHP techniques at $0.3 \mathrm{MPa}, A$. fulgidus growth in serum bottles with a $\sim 15 \mathrm{~mL}$ headspace was compared to $A$. fulgidus growth in $5 \mathrm{~mL}$ glass syringes with $\sim 0.5 \mathrm{~mL}$ gas phase incubated in the static pressure vessels. At these pressures a two-phase system is maintained in each experiment (serum bottle or glass syringe), and both phases achieve equivalent pressures. To achieve such low pressures in these vessels, an additional pressure gauge was placed onto the pressure line. This gauge was rated up to $0.7 \mathrm{MPa}$ so that $0.3 \mathrm{MPa}$ could be reached more precisely. Each serum bottle was subsampled six times during the course of each experiment.

Archaeoglobus fulgidus autotrophic HHP batch culture experiments were performed from 0.3 to $60 \mathrm{MPa}$ in $\sim 20 \mathrm{MPa}$ increments. Each HHP batch culture experiment was performed in triplicate with a negative control, along with the ambientpressure controls described above. Five static high-pressure vessels, containing two $5 \mathrm{~mL}$ glass syringes (one experiment and a negative control), were pressurized and decompressed only once for sampling to minimize decompression-repressurization cycles. Vessels were decompressed at an average rate of $19 \mathrm{MPa} / \mathrm{min}$. To obtain growth curves through the stationary phase, five $0.5 \mathrm{~mL}$ subsamples were taken over $\sim 145-215 \mathrm{~h}$, fixed with $2.5 \%(\mathrm{v} / \mathrm{v})$ gludaraldehyde, and later enumerated via light microscopy. Six subsamples were taken from experiments conducted in serum bottles.

\section{Direct Cell Counts}

For heterotrophic growth, cell densities were estimated by direct counting of cells fixed in $2.5 \%(\mathrm{v} / \mathrm{v})$ gludaraldehyde filtered onto $0.2 \mu \mathrm{m}$ black polycarbonate membranes (EMD Millipore) and stained with DAPI (4',6-diamidino-2-phenylindole dihydrochloride, Sigma Aldrich; Kepner and Pratt, 1994), under 200x magnification on an Olympus XM10 fluorescence microscope. For autotrophic growth, cell density was estimated by direct counts from cells fixed in $2.5 \%(\mathrm{v} / \mathrm{v})$ gludaraldehyde on a Thoma-chamber (depth: $0.02 \mathrm{~mm}$; Brand, Wertheim, Germany) using a light microscope (model XM: Olympus) under 80x magnification (e.g., Huber et al., 1989; Hei and Clark, 1994; Blöchl et al., 1997; Cario et al., 2016). To ensure consistency between the two counting methods, cells were enumerated in triplicate experiments by both DAPI and using a Thoma-chamber (depth: $0.02 \mathrm{~mm}$; Brand, Wertheim, Germany). Cell counts for each method were comparable (Supplementary Figure 2). Maximum cell densities were observed from stationary phase for all pressure conditions and error bars indicate standard deviation from at least triplicate experiments. Growth rates were calculated from the logarithmic growth phase slopes from triplicate batch culture experiments using the LINEST function in Excel. Error bars indicate the standard error from linear regressions of triplicate experiments.

\section{RESULTS}

Archaeoglobus fulgidus grew in a heterotrophic growth medium from 0.1 to $60 \mathrm{MPa}$ under $\mathrm{HHP}$ batch cultivation at $83^{\circ} \mathrm{C}$ (Figure 3A). Standard growth curves show similar growth patterns and cell densities up to $30 \mathrm{MPa}$, while slower growth was observed from 40 to $60 \mathrm{MPa}$; no notable increases in cell densities were measured at $70 \mathrm{MPa}$ (Figure 3A). Growth rates increased from 0.1 to $20 \mathrm{MPa}$ and decreased from 20 to $60 \mathrm{MPa}$ (Figure 3C). Maximum cell densities were similar from 0.1 to $30 \mathrm{MPa}$ and decreased with pressures above $30 \mathrm{MPa}$ (Figure 3E). The maximum growth rate for experiments that used the syringebased HHP techniques (e.g., syringes without headspace) was observed at $20 \mathrm{MPa}\left(0.15 \pm 0.005 \mathrm{hr}^{-1}\right.$, Figure $\left.3 \mathrm{C}\right)$, while the growth rate at $0.1 \mathrm{MPa}$ was $0.13 \pm 0.008 \mathrm{hr}^{-1}$ (Figure 3C), suggesting that $A$. fulgidus is a moderate piezophile under these conditions. Growth rates and maximum cell densities of A. fulgidus began to decline at $30 \mathrm{MPa}$ and $40 \mathrm{MPa}$, respectively (Figures 3C,E), and growth was barely detectable at $60 \mathrm{MPa}$ $\left(0.014 \pm 0.004 \mathrm{hr}^{-1}\right.$; Figures 3C,E). No growth was measured at $70 \mathrm{MPa}$ and the maximum cell density $\left(9.82 \pm 1.78 \times 10^{6}\right.$ cells/mL, Figures $3 \mathbf{A}, \mathbf{E}$ ) was only slightly higher than initial values $\left(9.04 \pm 1.3 \times 10^{6}\right.$ cells $/ \mathrm{mL}$, Figure $\left.3 \mathrm{E}\right)$. Even though growth did not occur at $70 \mathrm{MPa}$, cells exposed to $70 \mathrm{MPa}$ for $52 \mathrm{~h}$ that were subsequently transferred to $0.3 \mathrm{MPa}$ recovered to high cells densities $\left(5.6 \pm 0.25 \times 10^{8}\right.$ cells $\left./ \mathrm{mL}\right)$ after $64 \mathrm{~h}$ of growth at $0.3 \mathrm{MPa}$ (Figure 3E). A. fulgidus cells are normally coccoid but at growth pressures above $40 \mathrm{MPa}$, cell morphology was noticeably different (Figure 4). Cells that are normally coccoidal (Figure 4A) became irregular and elongated at $50 \mathrm{MPa}$ and $60 \mathrm{MPa}$ (Figure 4B). Similar morphological changes have been observed in other strains under HHP stress (e.g., Zobell and Oppenheimer, 1950; Donaldson et al., 1989).

In addition to the HHP batch cultivation techniques that employed headspace-free, stoppered syringes, growth experiments were also conducted in Balch tubes with a $17 \mathrm{~mL}$ gas headspace. These experiments were conducted at $0.3 \mathrm{MPa}$ and compared to experiments incubated at $0.3 \mathrm{MPa}$ in headspacefree syringes. In the latter experiments cell clustering was observed over a wide pressure range (0.1-50 $\mathrm{MPa})$, while aggregation was absent in Balch tubes (Supplementary Figure 3). Growth rates at $0.3 \mathrm{MPa}$ were also significantly different between the two techniques, and the overall highest growth rate $\left(0.17 \pm 0.015 \mathrm{hr}^{-1}\right.$; Figure $3 \mathrm{C}$ black circle) was observed in Balch tubes at near-ambient pressure conditions. Nonetheless, these experiments have no HHP counterpart and cannot be directly compared to growth in syringes.

Archaeoglobus fulgidus grew autotrophically from 0.3 to $40 \mathrm{MPa}$ at $83^{\circ} \mathrm{C}$ under HHP batch cultivation (Figure 3B). Similar growth patterns were observed from 0.3 to $40 \mathrm{MPa}$, though growth at $40 \mathrm{MPa}$ had a longer lag phase. Only slight growth was observed at $60 \mathrm{MPa}$ (Figure 3B). A. fulgidus was grown autotrophically at $0.3 \mathrm{MPa}$ in serum bottles with a headspace $\sim 38 \%$ by volume, and also grown using HHP methods in syringes with minimal headspace of $\sim 0.5 \mathrm{~mL}$ of $\mathrm{H}_{2}$ at $0.3 \mathrm{MPa}$ and no headspace from 10 to $60 \mathrm{MPa}$. For autotrophic growth experiments, similar growth rates were observed from 0.3 to $40 \mathrm{MPa}\left(0.022 \pm 0.002 \mathrm{hr}^{-1}, 0.0241 \pm 0.002 \mathrm{hr}^{-1}\right.$, and $0.0195 \pm 0.002 \mathrm{hr}^{-1}$, respectively), suggesting that $A$. fulgidus is a piezotolerant autotroph (Figure 3D). Slightly higher growth rates were observed in experiments conducted in serum bottles at $0.3 \mathrm{MPa}\left(0.0329 \pm 0.001 \mathrm{hr}^{-1}\right.$; Figure 3D black circle), 
Oliver et al.

High-Pressure Growth of A. fulgidus

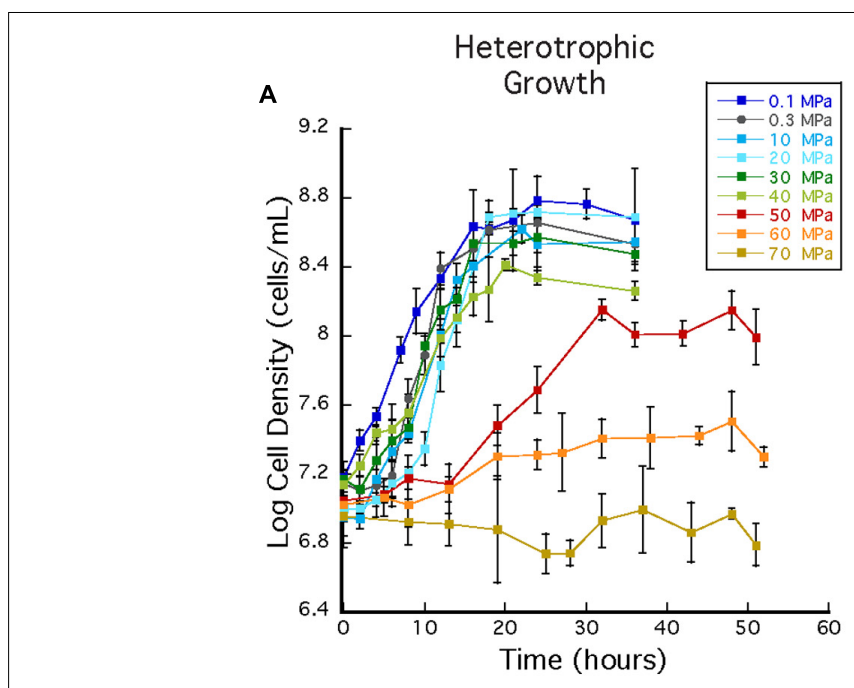

C

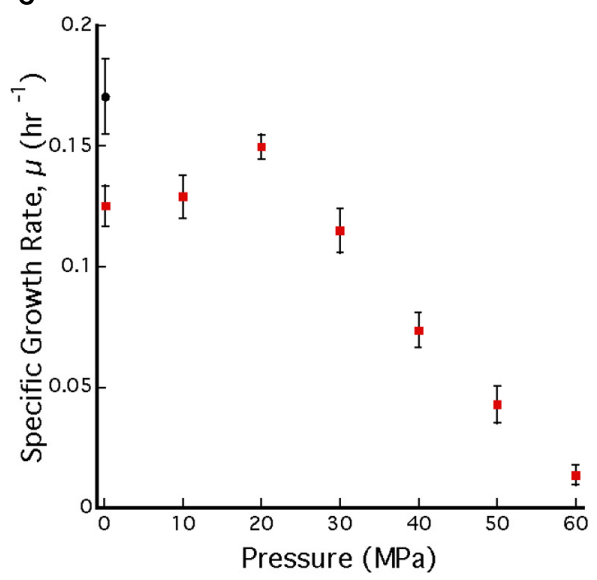

E

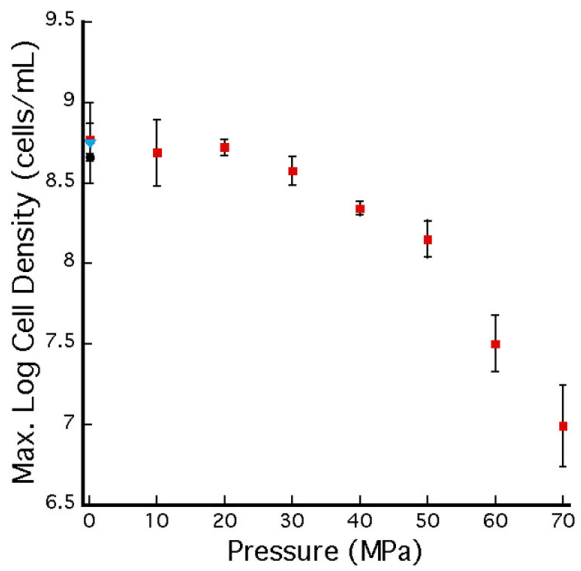

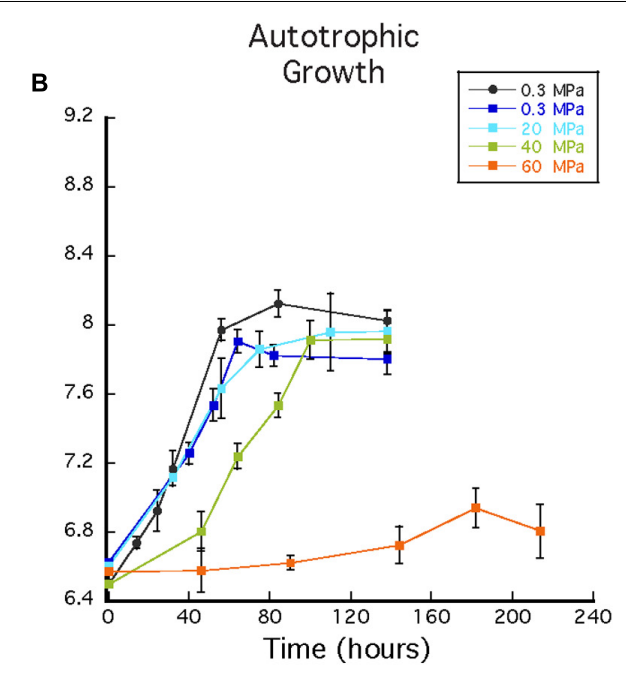
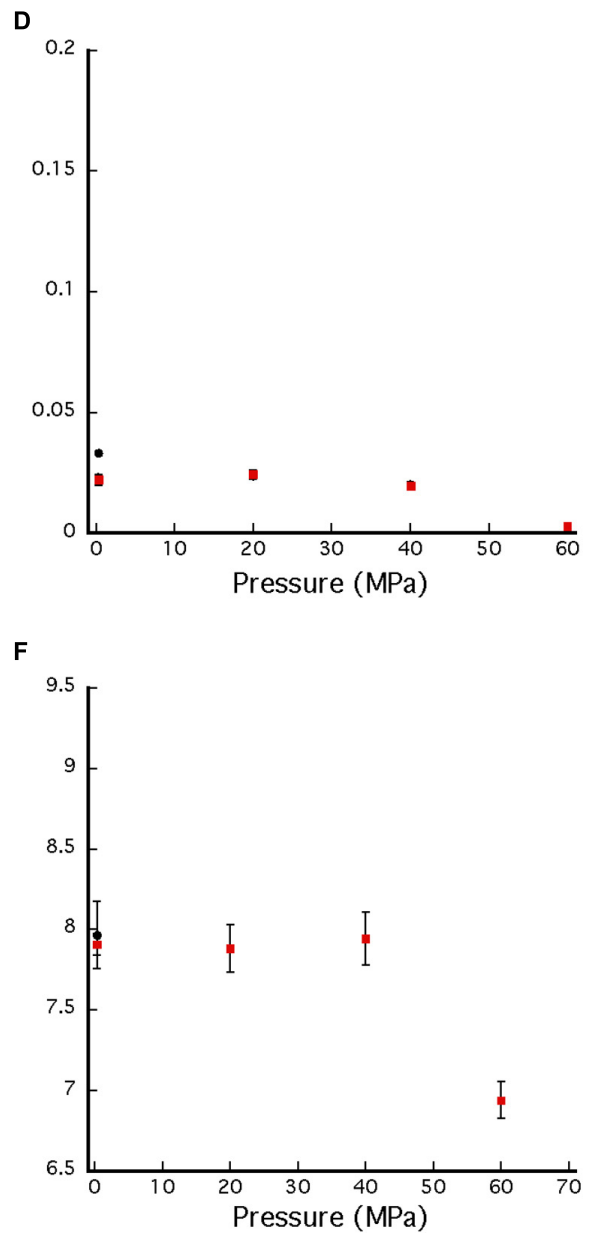

FIGURE 3 | (A) A. fulgidus heterotrophic HHP growth curves from 0.1 to $70 \mathrm{MPa}$ in syringes (colored squares) and Batch tubes at $0.3 \mathrm{MPa}$ (black circles).

(B) A. fulgidus autotrophic HHP growth curves from 0.3 to $60 \mathrm{MPa}$ in glass syringes (colored squares) and in serum bottles (black circles). (C) A. fulgidus HHP heterotrophic growth rates from 0.1 to $70 \mathrm{MPa}$ in syringes (red squares) and at $0.3 \mathrm{MPa}$ in Belch tubes (black circle) calculated from observed growth curves (A).

(D) A. fulgidus H HP autotrophic growth rates from 0.3 to $60 \mathrm{MPa}$ in syringes (red squares) and at $0.3 \mathrm{MPa}$ in serum bottles (black circle) calculated from growth curves (B). Growth rates were calculated from 3 to 5 data points measured from exponential growth from at least triplicate experiments. A. fulgidus HHP heterotrophic (E) and autotrophic (F) maximum cell densities measured when grown in syringes (red squares), Bach tubes or serum bottles (black circles), and at $0.3 \mathrm{MPa}$ after exposure to $70 \mathrm{MPa}$ [blue triangle in (A)]. No growth was observed at $70 \mathrm{MPa}$. Error bars represent the standard deviation from at least triplicate experiments.

Frontiers in Microbiology | www.frontiersin.org

7

June 2020 | Volume 11 | Article 1023 

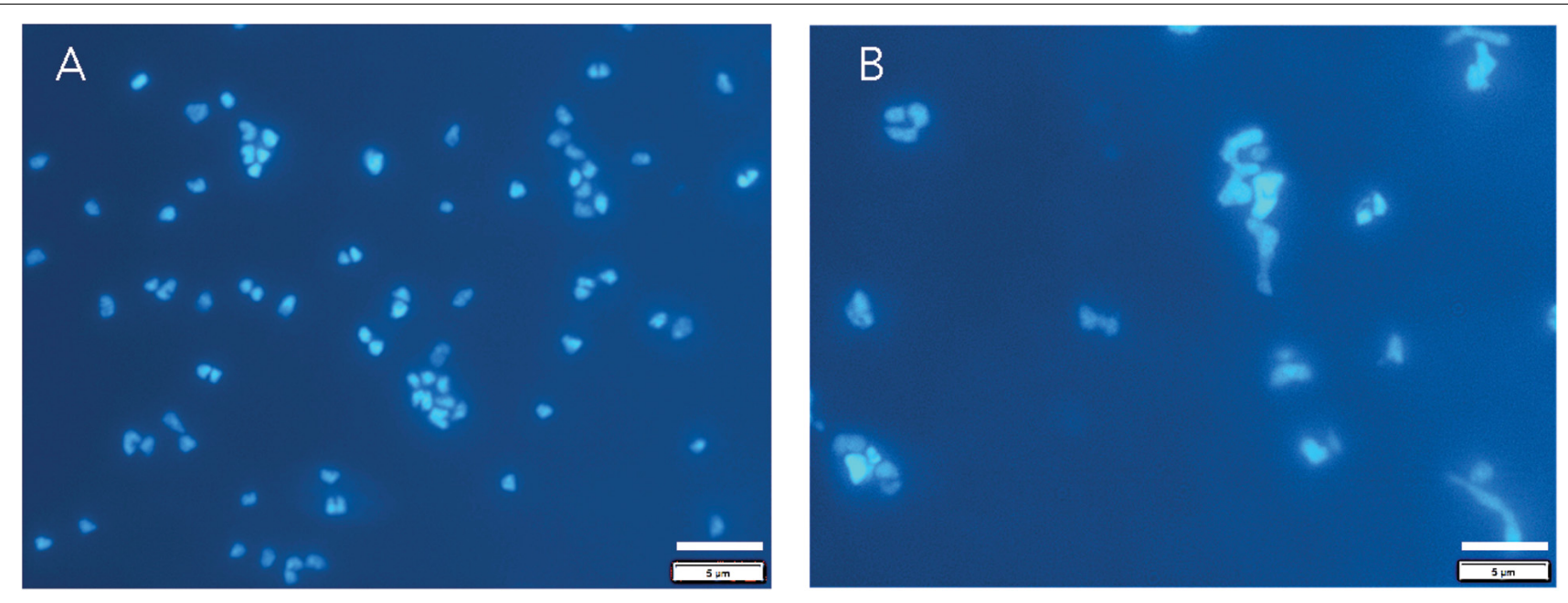

FIGURE 4 | DAPI stained A. fulgidus cells grown in a heterotrophic medium after $24 \mathrm{~h}$ of growth at $0.1 \mathrm{MPa}(\mathbf{A})$ in Balch tubes and at 50 MPa (B) in syringes. Dilution factors for were $20 \times(\mathbf{A})$ and $4 \times(\mathbf{B})$. Bar is $5 \mu \mathrm{m}$.

likely due to the presence of an $\mathrm{H}_{2} / \mathrm{CO}_{2}$ gas phase. Again, cultivation in serum bottles at $0.3 \mathrm{MPa}$ is not directly comparable to growth in syringes under HHP culture conditions. For HHP batch cultivation, similar maximum cell densities were measured at $0.3-40 \mathrm{MPa}\left(9.22 \pm 1.33 \times 10^{7} \mathrm{cells} / \mathrm{mL}-\right.$ $1.38 \pm 0.215 \times 10^{8}$ cells $/ \mathrm{mL}$; Figure 3F). Minor growth was measured at $60 \mathrm{MPa}$ with an average maximum cell density that reached $8.67 \pm 1.29 \times 10^{6}$ cells $/ \mathrm{mL}$ from an average inoculum cell density of $3.16 \pm 1.65 \times 10^{6}$ cells $/ \mathrm{mL}$ (Figure 3F). As expected, autotrophic growth was slower and had lower cell densities compared to heterotrophic growth (Prieur and Marteinsson, 1998). Nevertheless, these results indicate that A. fulgidus is a piezotolerant autotroph up to $40 \mathrm{MPa}$.

Repeated cycles of decompression and repressurization did not significantly impact heterotrophic growth of A. fulgidus from 10 to $50 \mathrm{MPa}$. Figure 5 shows that cell density measurements in experiments with only one decompression/repressurization cycle were similar to those with multiple cycles. Slightly higher growth densities at 10-30 MPa for cells decompressed multiple times versus once might suggest that repressurization may have a positive impact on growth (Yayanos, 1995). Decompression may have had a negative impact on cells decompressed multiple times at $60 \mathrm{MPa}$, as maximum cell densities at $60 \mathrm{MPa}$ for cells decompressed once were $3.02 \pm 0.10 \times 10^{7}$ cells $/ \mathrm{mL}$ and those decompressed multiple times were $2.15 \pm 0.59 \times 10^{7}$ cells $/ \mathrm{mL}$. However, low growth yields at $60 \mathrm{MPa}$ contribute to a low $R$-value, making it difficult to discern any affects from subsampling decompression. Nevertheless, these results confirm high-pressure growth of A. fulgidus up to $50 \mathrm{MPa}$ with cellular viability unaffected by periodic decompressions.

Archaeoglobus fulgidus (type strain VC16) is capable of growing at HHP conditions both heterotrophically and autotrophically and displays both piezophilic and piezotolerant behavior depending on metabolic strategy. Growing heterotrophically, A. fulgidus is a moderate piezophile, with maximum specific growth rates measured at $20 \mathrm{MPa}$ for the cultivation conditions described here. On the other hand, A. fulgidus growth rates and stationary-phase cell densities were similar for autotrophy from 0.3 to $40 \mathrm{MPa}$, indicating only piezotolerance for these autotrophic conditions. Interestingly,

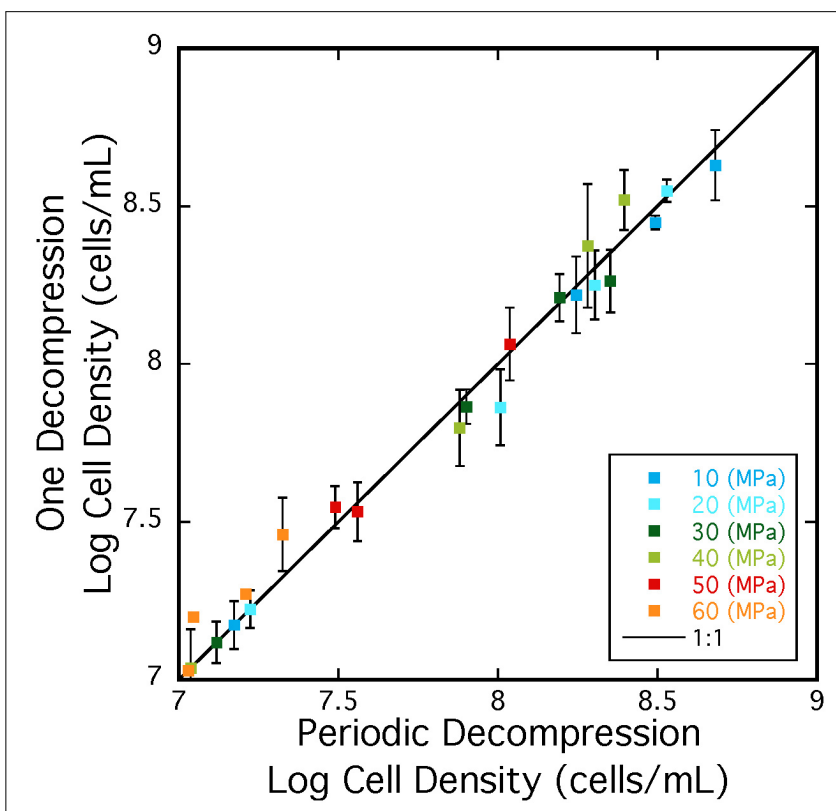

FIGURE 5 | Cell densities A. fulgidus grown in a heterotrophic medium, and exposed to one cycle ( $y$-axis) or multiple cycles of decompression/repressurization ( $x$-axis) from 10 to $60 \mathrm{MPa}$. The 1:1 correspondence is shown as a black line. Best-fit lines and respective $R$-values are; $y=-0.23784+0.96712 \times R=0.999(10 \mathrm{MPa})$, $y=-0.011249+0.99586 x R=0.991(20 \mathrm{MPa}), y=-0.29188+0.95957 x$ $R=0.996(30 \mathrm{MPa}), y=-0.65328+1.087 \times R=0.993(40 \mathrm{MPa})$, $y=-0.014095+1.0042 x R=0.990(50 \mathrm{MPa}), y=-1.1686+31.1757 x$ $R=0.928$ (60 MPa). Error bars are deviations from the average of triplicate experiments. 
growth rates under traditional batch culture generated different results from the HHP syringe-based techniques at $0.1 \mathrm{MPa}$ or $0.3 \mathrm{MPa}$ for both metabolisms, highlighting that different cultivation methods can impact microbial growth patterns. Additionally, cell clustering in experiments using the HHP batch cultivation technique was observed over most of the pressure range $(0.1-50 \mathrm{MPa})$. The cause for cell clustering was not resolved during this study, however, additional analyses are underway to investigate this physiological response. Taken together, these results suggest that $A$. fulgidus is capable of both heterotrophic and autotrophic growth in high-pressure, subsurface, marine environments.

\section{DISCUSSION}

Archaeoglobus fulgidus type strain VC-16 was originally isolated from a shallow marine hydrothermal system, and its discovery was notable as this species was the only archaeal sulfate reducer known at that time (Stetter et al., 1987, 1990). Initially this species was thought to be the "shallow"-dwelling Archaeoglobus analog to Archaeoglobus profundus, isolated from the hot sediments of Guaymas Basin at $\sim 2 \mathrm{~km}$ depth $(\sim 20 \mathrm{MPa}$; Burggraf et al., 1990). Yet since its discovery, several other A. fulgidus strains have been isolated from various deep environments (Table 1), expanding the habitat range for this species. These include three strains isolated from multiple oil reservoirs at depths of up to $4 \mathrm{~km}$ (corresponding to $\sim 40 \mathrm{MPa}$ hydrostatic pressure and even higher lithostatic pressures; Stetter et al., 1993; Beeder et al., 1994; L'Haridon et al., 1995), and two additional A. fulgidus strains isolated from the Paris Basin at $1.9 \mathrm{~km}$ (Fardeau et al., 2009). Furthermore, this species is commonly identified in various midocean ridge vent systems including the Mid-Atlantic Ridge, the Juan de Fuca Ridge, and the East Pacific Rise (e.g., Reysenbach et al., 1998, 2000; Schrenk et al., 2003), with depths between $\sim 2$ and $3.5 \mathrm{~km}(\sim 20-35 \mathrm{MPa})$. Several other Archaeoglobus species have been isolated from various subsurface environments (Table 1), confirming the ubiquity of this genus in high-pressure, subsurface ecosystems. As most of the sampling, analysis and enrichment techniques applied to samples from these highpressure environments usually involves sample decompression (e.g., Jannasch and Wirsen, 1973; Bianchi et al., 1999; Peoples and Bartlett, 2017; Cario et al., 2019), recovery of this and related species is consistent with the results reported here showing that $A$. fulgidus is largely unaffected by decompression and repressurization (Figure 5). Other strains that are sensitive to decompression are likely excluded from similar analyses via decompression sample bias.

This widespread distribution of Archaeoglobus species in subsurface high-pressure environments stands in contrast to the paucity of evidence confirming their growth at elevated pressures. The only other reported HHP growth experiments performed on A. fulgidus was strain TF2 (Stetter et al., 1993), which was isolated from a $\sim 3 \mathrm{~km}$ deep oil reservoir and reported to grow at $42 \mathrm{MPa}$ on crude oil as a sole growth substrate (Stetter et al., 1993), reflecting its adaptation to its immediate habitat. Also, an archaeal strain (L3), most closely related to A. fulgidus, was isolated from a $2 \mathrm{~km}$ geothermal well and was successfully cultivated at $\sim 0.2 \mathrm{MPa}$ under autotrophic conditions $\left(\mathrm{H}_{2}\right.$ and $\mathrm{CO}_{2}$ as a sole carbon source in the presence of thiosulfate; Fardeau et al., 2009). Strain L3 exhibited several phenotypic differences from the A. fulgidus type strain VC-16 and required yeast extract for growth (Fardeau et al., 2009). In contrast, the autotrophic HHP experiments reported here for type strain VC16 extend the autotrophic pressure range for growth to $40 \mathrm{MPa}$, without supplemental vitamins or yeast extract. These differences once again highlight the significant differences in physiological response to elevated pressure, even within a species.

Consistent with the widespread distribution of Archaeoglobus species in high-pressure environments, the experiments reported here show that the A. fulgidus type strain VC-16 is moderately piezophilic for chemoorganoheterotrophy, and piezotolerant for chemolithoautotrophy. This adds to the currently identified 58 characterized piezotolerant and piezophilic microorganisms (Jebbar et al., 2015; reviewed in Fichtel et al., 2015; Dalmasso et al., 2016; Kusube et al., 2017; Liu et al., 2018; Cario et al., 2019; Yu et al., 2019), a majority of which (52) are chemoorganoheterotrophs. In the HHP experiments reported here, the physiologic responses of A. fulgidus depended primarily on metabolic strategy. Under autotrophic conditions, the type strain was piezotolerant with similar growth rates at 0.3 and $20 \mathrm{MPa}$. In contrast, $A$. fulgidus VC-16 growing heterotrophically was a moderate piezophile with a maximum growth rate at $20 \mathrm{MPa}$. Other studies have shown both piezotolerant and piezophilic behaviors within a single species, but these variations have more commonly corresponded to temperature differences. For example, Nogi et al. (1998) found that Moritella japonica grew optimally as a piezophile at $15^{\circ} \mathrm{C}$ and $50 \mathrm{MPa}$ but was piezotolerant at $10^{\circ} \mathrm{C}$, with an optimum growth pressure at 0.1 MPa. Similarly, the hyperthermophilic archaeon, Thermococcus eurythermalis, exhibited piezophily at $95^{\circ} \mathrm{C}$, but was more piezotolerant at $85^{\circ} \mathrm{C}$ (Zhao et al., 2015). All of the HHP experiments described here were carried out at $83^{\circ} \mathrm{C}$, this strain's optimum temperature at $0.1 \mathrm{MPa}$ (Stetter, 1988), thus it remains unknown if $A$. fulgidus' piezophily is temperature dependent. To our knowledge, HHP growth for both heterotrophy and autotrophy within a single species has not been characterized previously (see Jebbar et al., 2015 for a review). The thermophilic piezophile, Piezobacter thermophilus, was shown to be a strict piezophile under autotrophic conditions, and while this species did utilize organic compounds at ambient pressures, HHP organotrophy was not confirmed (Takai et al., 2009). Furthermore, several mesophilic sulfate reducers are known to grow both autotrophically and heterotrophically (e.g., Desulfobacterium autotrophicum, Desulfobacterium vacuolatum, Desulfobacter hydrogenophilus; Brysch et al., 1987), but their ability to grow autotrophically and heterotrophically at high pressure is unknown since only a handful of mesophilic sulfate reducers have been grown at pressure (e.g., Bale et al., 1997; Alazard et al., 2003; Khelaifia et al., 2011; Williamson et al., 2018). As A. fulgidus employs both metabolic strategies at elevated pressure, this strain could serve as a model to further explore the enzymatic and bioenergetic distinctions between heterotrophy and autotrophy at elevated pressures. 
The increased growth rates of A. fulgidus carrying out heterotrophic sulfate reduction at elevated pressures suggest an important role for this hyperthermophilic sulfate reducer in high-temperature, subsurface environments. In general, heterotrophic sulfate reduction is a key metabolism in a variety of anoxic, organic-rich environments. In marine sediments, sulfate reduction can significantly impact sedimentary geochemical profiles (Goldhaber, 2003), and sulfate reduction and anaerobic oxidation of methane (AOM) dominate throughout methane rich marine sediments and play an important role in global carbon cycling (Hinrichs and Boetius, 2002; Joye et al., 2004; Meulepas et al., 2010). In subsurface oil reservoirs, sulfate reduction is the main contributor to crude oil degradation, negatively impacting both economic and safety factors (e.g., Gittel et al., 2009; Gieg et al., 2010, 2011). The importance of Archaeoglobus species in these subsurface hydrothermal environments has always been inferred from its ubiquity in phylogenetic diversity studies of these ecosystems, but the specifics of its high-pressure metabolism have been unknown. As the first isolated sulfate-reducing archaeon (Stetter, 1988; Thauer and Kunow, 1995; Rabus et al., 2013), A. fulgidus and other members of this genus were recognized as filling a specific ecological niche in hot, sulfate-rich, anoxic surface marine environments. With optimum growth temperatures between 75 and $90^{\circ} \mathrm{C}$, these hyperthermophilic sulfate reducing archaea thrive between the thermophilic sulfate reducing bacteria (optimum growth temperatures typically between 40 and $70^{\circ} \mathrm{C}$; Rabus et al., 2013) and the hyperthermophilic sulfur metabolizing archaea (optimum growth temperatures typically between $\sim 70$ and $100^{\circ} \mathrm{C}$; Reysenbach et al., 2000; Huber et al., 2006; Hartzell and Reed, 2006). The ubiquity of Archaeoglobus species in the subsurface suggests that they play a similar role in subsurface environments.

Furthermore, recent reports suggest that both elevated temperature and elevated pressure are critical parameters constraining the ecological niche that sulfate reducers occupy in hydrothermal sediments. For example, in Guaymas Basin, Kallmeyer and Boetius (2004) found that the highest sulfate reduction rates occurred at elevated pressures (22-45 $\mathrm{MPa}$ ) and at higher temperatures than AOM, suggesting that sulfate reduction is mainly responsible for carbon cycling in higher temperature sediments, and that sulfate reduction rates are pressure-dependent. As a hyperthermophile that can grow up to $95^{\circ} \mathrm{C}$ (Hartzell et al., 1999), A. fulgidus VC-16 could cycle carbon in this high-temperature niche, and the results described here expand the habitat of $A$. fulgidus to include highpressure environments. Our results expand the pressure range of A. fulgidus VC-16 to $0.1-60 \mathrm{MPa}$ for heterotrophic metabolisms and $0.1-40 \mathrm{MPa}$ for autotrophy. These pressures encompass the average ocean floor depth, $3.688 \mathrm{~km}$ (i.e., $\sim 37 \mathrm{MPa}$ ) and associated hydrothermal marine sediments, depths of many oil field reservoirs ranging from $\sim 1-3 \mathrm{~km}$ depth (Pinder, 2001), and the average depth of black smoker hydrothermal vents at $\sim 2.1 \mathrm{~km}$ (i.e., $\sim 21 \mathrm{MPa}$ ), and even the deepest known hydrothermal system, the Mid Cayman Rise, where members of the Archaeoglobales have been identified with 16S amplicon sequencing (Reveillaud et al., 2016). With the ability to carry out heterotrophic sulfate reduction at both high-temperature and high-pressure conditions, $A$. fulgidus likely plays a significant role in cycling carbon and sulfur in these environments.

\section{CONCLUSION}

Overall, the high-pressure growth of $A$. fulgidus is unsurprising for its consistency with observations of this species throughout both shallow- and deep-marine hydrothermal systems. However, the expansive pressure range and metabolic variability across that pressure range once again underscores that this species and others within this genus require further investigation, and can serve as model organisms to better understand microbial physiology in hydrothermal environments. A. fulgidus would be an ideal subject for a vast array of analyses (molecular and biogeochemical) over a range of pressure conditions. For instance, experiments to explore membrane structure and functionality under different pressure, decompression, and metabolic conditions may lend some insight into this species' ability to adapt to both surface and subsurface environments. Additionally, other Archaeoglobus species that have been isolated from high-pressure environments (Table 1) are likely also piezotolerant and piezophilic. Comparison across these species at both ambient and HHP conditions, especially focusing on comparative transcriptomics and proteomics, could reveal mechanisms of pressure adaptation. Finally, as a majority of bacterial and archaeal cells inhabit high-pressure environments (e.g., Whitman et al., 1998; Jebbar et al., 2015; Bar-On et al., 2018), further HHP batch cultivation performed on other extremophiles is necessary to expand our understanding of how microorganisms regulate pressure changes and how that governs their distribution on Earth.

\section{DATA AVAILABILITY STATEMENT}

The raw data supporting the conclusion of this article will be made available by the authors, without undue reservation, to any qualified researcher.

\section{AUTHOR CONTRIBUTIONS}

$\mathrm{GO}, \mathrm{AC}$, and $\mathrm{KR}$ designed this research project, analyzed the data. GO performed the experiments and collected the data, wrote the original draft. KR and AC edited and wrote sections of the manuscript. All authors contributed to revisions of the manuscript, tables, and figures and approved the submitted version.

\section{FUNDING}

Funding for this work was provided by the NASA Exobiology and PSTAR Programs (NNX13AP2G9 and 80NSSC17K0252 to KR), the Deep Carbon Observatory (Subawards: 10371-07, 1056101, and 10311-11 to KR), an NSF Graduate Fellowship (FAIN 
1247271 and 1744655 to GO), and a GSA Research Grant to GO. Additional support was provided by startup funds from Rensselaer Polytechnic Institute to KR.

\section{ACKNOWLEDGMENTS}

We thank Dr. Bruce Watson for generously gifting us four pressure vessels that allowed us to perform these growth experiments and Dr. Ken Takai for helping us improve our

\section{REFERENCES}

Abe, F., and Horikoshi, K. (2001). The biotechnological potential of piezophiles. Trends Biotechnol. 19, 102-108. doi: 10.1016/S0167-7799(00)01539-0

Abe, F., Kato, C., and Horikoshi, K. (1999). Pressure-regulated metabolism in microorganisms. Trends Microbiol. 7, 447-453. doi: 10.1016/S0966-842X(99) 01608-X

Achenbach-Richter, L., Stetter, K. O., and Woese, C. R. (1987). A possible biochemical missing link among archaebacteria. Nature 327, 348-349. doi: 10. 1038/327348a0

Alain, K., Marteinsson, V., Miroshnichenko, M. L., Bonch-osmolovskaya, E. A., Prieur, D., and Birrien, J. (2002). Marinitoga piezophilia sp. nov., a rod-shaped, thermo-piezophilic bacterium isolated under high hydrostatic pressure from a deep-sea hydrothermal vent. Int. J. Syst. Evol. Microbiol. 52, 1331-1339. doi: 10.1099/ijs.0.02068-0

Alazard, D., Dukan, S., Urios, A., Verhé, F., Bouabida, N., Morel, F., et al. (2003). Desulfovibrio hydrothermalis sp. nov., a novel sulfate-reducing bacterium isolated from hydrothermal vents. Int. J. Syst. Evol. Microbiol. 53, 173-178. doi: 10.1099/ijs.0.02323-0

Balch, W. E., Fox, G. E., Magrum, L. J., Woese, C. R., and Wolfe, R. S. (1979). Methanogens: reevaluation of a unique biological group. Microbiolol. Rev. 43, 260-296. doi: 10.1016/j.watres.2010.10.010

Bale, S. J., Goodman, K., Rochelle, P. A., Marchesi, J. R., Fry, J. C., Weightman, A. J., et al. (1997). Desulfovibrio profundus sp. nov., a novel barophilic sulfatereducing bacterium from deep sediment layers in the Japan sea. Int. J. Syst. Bacteriol. 47, 515-521. doi: 10.1099/00207713-47-2-515

Bar-On, Y. M., Phillips, R., and Milo, R. (2018). The biomass distribution on Earth. Proc. Natl. Acad. Sci. U.S.A. 115, 6506-6511. doi: 10.1073/pnas.1711842115

Bartlett, D. H. (2002). Pressure effects on in vivo microbial processes. Biochim. Biophys. Acta 1595, 367-381. doi: 10.1016/S0167-4838(01)00357-0

Beeder, J., Nilsen, R. K., Rosnes, J. T., Torsvik, T., and Lien, T. (1994). Archaeoglobus fulgidus isolated from hot North Sea oil field waters. Appl. Environ. Microbiol. 60, 1227-1231. doi: 10.1128/aem.60.4.1227-1231.1994

Bernhardt, G., Jaenicke, R., and Lüdemann, H. D. (1987). High-pressure equipment for growing methanogenic microorganisms on gaseous substrates at high temperature. Appl. Environ. Microbiol. 53, 1876-1879. doi: 10.1126/science. 1086823

Bernhardt, G., Jaenicke, R., Lüdemann, H. D., König, H., and Stetter, K. O. (1988). High pressure enhances the growth rate of the thermophilic archaebacterium Methanococcus thermolithotrophicus without extending its temperature range. Appl. Environ. Microbiol. 54, 1258-1261. doi: 10.1128/aem.54.5.1258-1261. 1988

Bianchi, A., Garcin, J., and Tholosan, O. (1999). A high-pressure serial sampler to measure microbial activity in the deep sea. Deep-Sea Res. Part I 46, 2129-2142. doi: 10.1016/S0967-0637(99)00039-4

Birrien, J. L., Zeng, X., Jebbar, M., Cambon-Bonavita, M. A., Quérellou, J., Oger, P., et al. (2011). Pyrococcus yayanosii sp. nov., an obligate piezophilic hyperthermophilic archaeon isolated from a deep-sea hydrothermal vent. Int. J. Syst. Evol. Microbiol. 61, 2827-2831. doi: 10.1099/ijs.0.024653-0

Blöchl, E., Rachel, R., Burggraf, S., Hafenbradl, D., Jannasch, H. W., and Stetter, K. O. (1997). Pyrolobus fumarii, gen. and sp. nov., represents a novel group of archaea, extending the upper temperature limit for life to 113 degrees C. Extremophiles 1, 14-21. doi: 10.1007/s007920050010 autotrophic HHP techniques for which growth would not have been successful. We also thank two reviewers whose thoughtful comments have greatly improved this contribution.

\section{SUPPLEMENTARY MATERIAL}

The Supplementary Material for this article can be found online at: https://www.frontiersin.org/articles/10.3389/fmicb. 2020.01023/full\#supplementary-material

Boonyaratanakornkit, B., Córdova, J., Park, C. B., and Clark, D. S. (2006). Pressure affects transcription profiles of Methanocaldococcus jannaschii despite the absence of barophilic growth under gas-transfer limitation. Environ. Microbiol. 8, 2031-2035. doi: 10.1111/j.1462-2920.2006.01083.x

Brysch, K., Schneider, C., Fuchs, G., and Widdel, F. (1987). Lithoautotrophic growth of sulfate-reducing bacteria, and description of Desulfobacterium autotrophicum gen. nov., sp. nov. Arch. Microbiol. 148, 264-274. doi: 10.1007/ BF00456703

Burggraf, S., Jannasch, H. W., Nicolaus, B., and Stetter, K. O. (1990). Archaeoglobus profundus sp. nov., represents a new species within the sulfate-reducing archaebacteria. Syst. Appl. Microbiol. 13, 24-28. doi: 10.1016/S0723-2020(11) 80176-1

Cario, A., Jebbar, M., Thiel, A., Kervarec, N., and Oger, P. M. (2016). Molecular chaperone accumulation as a function of stress evidences adaptation to high hydrostatic pressure in the piezophilic archaeon Thermococcus barophilus. Sci. Rep. 6, 1-8. doi: 10.1038/srep29483

Cario, A., Oliver, G. C., and Rogers, K. L. (2019). Exploring the deep marine biosphere: challenges, innovations, and opportunities. Front. Earth Sci. 7:225. doi: 10.3389/feart.2019.00225

Charlesworth, J., and Burns, B. P. (2016). Extremophilic adaptations and biotechnological applications in diverse environments. AIMS Microbiol. 2, 251-261. doi: 10.3934/microbiol.2016.3.251

Dalmasso, C., Oger, P., Selva, G., Courtine, D., L'Haridon, S., Garlaschelli, A., et al. (2016). Thermococcus piezophilus sp. nov., a novel hyperthermophilic and piezophilic archaeon with a broad pressure range for growth, isolated from a deepest hydrothermal vent at the Mid-Cayman Rise. Syst. Appl. Microbiol. 39, 440-444. doi: 10.1016/j.syapm.2016.08.003

Donaldson, E. C., Knapp, R. M., Yen, T. F., and Chilingarian, G. V. (1989). The subsurface environment. Dev. Petrol. Sci. 22, 15-36. doi: 10.1016/S03767361(09)70090-1

Erauso, G., Reysenbach, A. L., Godfroy, A., Meunier, J. R., Crump, B., Partensky, F., et al. (1993). Pyrococcus abyssi sp. nov., a new hyperthermophilic archaeon isolated from a deep-sea hydrothermal vent. Arch. Microbiol. 160, 338-349. doi: 10.1007/BF00252219

Fang, J., Zhang, L., and Bazylinski, D. A. (2010). Deep-sea piezosphere and piezophiles: geomicrobiology and biogeochemistry. Trends Microbiol. 18, 413422. doi: 10.1016/j.tim.2010.06.006

Fardeau, M.-L., Goulhen, F., Bruschi, M., Khelifi, N., Cayol, J.-L., Ignatiadis, I., et al. (2009). Archaeoglobus fulgidus and Thermotoga efii, thermophilic isolates from deep geothermal water of the Paris Basin. Geomicrobiol. J. 26, 119-130. doi: 10.1080/01490450802674970

Fichtel, K., Logemann, J., Fichtel, J., Rullkötter, J., Cypionka, H., and Engelen, B. (2015). Temperature and pressure adaptation of a sulfate reducer from the deep subsurface. Front. Microbiol. 6:1078. doi: 10.3389/fmicb.2015. 01078

Garel, M., Bonin, P., Martini, S., Guasco, S., Roumagnac, M., Bhairy, N., et al. (2019). Pressure-retaining sampler and high-pressure systems to study deepsea microbes under in situ conditions. Front. Microbiol. 10:453. doi: 10.3389/ fmicb.2019.00453

Gieg, L. M., Davidova, I. A., Duncan, K. E., and Suflita, J. M. (2010). Methanogenesis, sulfate reduction and crude oil biodegradation in hot Alaskan oilfields. Environ. Microbiol. 12, 3074-3086. doi: 10.1111/j.1462-2920.2010. 02282.x 
Gieg, L. M., Jack, T. R., and Foght, J. M. (2011). Biological souring and mitigation in oil reservoirs. Appl. Microbiol. Biotechnol. 92, 263-282. doi: 10.1007/s00253011-3542-6

Gittel, A., Sørensen, K. B., Skovhus, T. L., Ingvorsen, K., and Schramm, A. (2009). Prokaryotic community structure and sulfate reducer activity in water from high-temperature oil reservoirs with and without nitrate treatment. Appl. Environ. Microbiol. 75, 7086-7096. doi: 10.1128/AEM.01123-09

Goldhaber, M. B. (2003). Sulfur-rich sediments. Treatise Geochem. 7-9, 257-288. doi: 10.1016/B0-08-043751-6/07139-5

Hartzell, P., and Reed, D. W. (2006). The genus Archaeoglobus. Prokaryotes 3, 82-100. doi: 10.1007/0-387-30747-8

Hartzell, P. L., Millstein, J., and Lapaglia, C. (1999). Biofilm formation in hyperthermophilic archaea. Methods Enzymol. 310, 335-349. doi: 10.1016/ S0076-6879(99)10027-2

Hei, D. J., and Clark, D. S. (1994). Pressure stabilization of proteins from extreme thermophiles. Appl. Environ. Microbiol. 60, 932-939. doi: 10.1038/nature 06899

Hinrichs, K.-U., and Boetius, A. (2002). “The anaerobic oxidation of methane: new insights in microbial ecology and biogeochemistry," in Ocean Margin Systems, eds G. Wefer, D. Billett, D. Hebbeln, B. B. Jørgensen, M. Schlüter, T. C. E. van Weering, (Berlin: Springer), 457-477. doi: 10.1007/978-3-662-05127-6_28

Hocking, W. P., Stokke, R., Roalkvam, I., and Steen, I. H. (2014). Identification of key components in the energy metabolism of the hyperthermophilic sulfatereducing archaeon Archaeoglobus fulgidus by transcriptome analyses. Front. Microbiol. 5:95. doi: 10.3389/fmicb.2014.00095

Holden, J. F., and Baross, J. A. (1993). Enhanced thermotolerance and temperatureinduced changes in protein composition in the hyperthermophilic archaeon ES4. J. Bacteriol. 175, 2839-2843. doi: 10.1128/jb.175.10.2839-2843.1993

Holden, J. F., and Baross, J. A. (1995). Enhanced thermotolerance by hydrostatic pressure in the deep-sea hyperthermophile Pyrococcus strain ES4. FEMS Microbiol. Ecol. 18, 27-33. doi: 10.1016/0168-6496(95)00037-B

Huber, H., Huber, R., and Stetter, K. O. (2006). Thermoproteales. Prokaryotes 3 , 10-22. doi: 10.1007/0-387-30743-5_2

Huber, H., Jannasch, H., Rachel, R., Fuchs, T., and Stetter, K. O. (1997). Archaeoglobus veneficus sp nov, a novel facultative chemolithoautotrophic hyperthermophilic sulfite reducer, isolated from abyssal black smokers. Syst. Appl. Microbiol. 20, 374-380. doi: 10.1016/S0723-2020(97)80005-7

Huber, R., Woese, C. R., Langworthy, T. A., Fricke, H., and Stetter, K. O. (1989). Thermosipho africanus gen. nov., represents a new genus of thermophilic eubacteria within the "Thermotogales.". Syst. Appl. Microbiol. 12, 32-37. doi: 10.1016/S0723-2020(89)80037-2

Jaenicke, R. (1983). Biochemical processes under high hydrostatic pressure Physico-chemical approaches to barosensitivity. Naturwissenschaften 70, 332 341. doi: 10.1007/BF00444207

Jannasch, H. W., and Taylor, C. D. (1984). Deep-sea microbiology. Annu. Rev. Microbiol. 38, 487-514.

Jannasch, H. W., and Wirsen, C. O. (1973). Deep-sea microorganisms: in situ response to nutrient enrichment. Science 180, 641-643. doi: 10.1126/science. 180.4086.641

Jannasch, H. W., Wirsen, C. O., Molyneaux, S. J., and Langworthy, T. A. (1992). Comparative physiological studies on hyperthermophilic archaea isolated from Deep-sea hot vents with emphasis on Pyrococcus strain GB-D. Appl. Environ. Microbiol. 58, 3472-3481.

Jebbar, M., Franzetti, B., Girard, E., and Oger, P. (2015). Microbial diversity and adaptation to high hydrostatic pressure in deep-sea hydrothermal vents prokaryotes. Extremophiles 19, 721-740. doi: 10.1007/s00792-015-0760-3

Joye, S. B., Boetius, A., Orcutt, B. N., Montoya, J. P., Schulz, H. N., Erickson, M. J., et al. (2004). The anaerobic oxidation of methane and sulfate reduction in sediments from Gulf of Mexico cold seeps. Chem. Geol. 205, 219-238. doi: 10.1016/j.chemgeo.2003.12.019

Kallmeyer, J., and Boetius, A. (2004). Effects of temperature and pressure on sulfate reduction and anaerobic oxidation of methane in hydrothermal sediments of Guaymas Basin. Appl. Environ. Microbiol. 70, 1231-1233. doi: 10.1128/AEM. 70.2.1231-1233.2004

Kallmeyer, J., Ferdelman, T. G., Jansen, K. H., and Jørgensen, B. B. (2003). A high-pressure thermal gradient block for investigating microbial activity in multiple deep-sea samples. J. Microbiol. Methods 55, 165-172. doi: 10.1016/ S0167-7012(03)00138-6
Kaneshiro, S. M., and Clark, D. S. (1995). Pressure effects on the composition and thermal behavior of lipids from the deep-sea thermophile Methanococcus jannaschii. J. Bacteriol. 177, 3668-3672. doi: 10.1128/jb.177.13.3668-3672.1995

Kato, C., Nogi, Y., and Arakawa, S. (2008). "Isolation, cultivation, and diversity of deep-sea piezophiles," in High-Pressure Microbiology, eds C. Michiels, D. H. Bartlett, and A. Aertsen, (Washington, DC: ASM Press), 203-218.

Kepner, R. L., and Pratt, J. R. (1994). Use of fluorochromes for direct enumeration of total bacteria in environmental samples: past and present. Microbiol. Rev. 58, 603-615. doi: 10.1128/mmbr.58.4.603-615.1994

Khelaifia, S., Fardeau, M. L., Pradel, N., Aussignargues, C., Garel, M., Tamburini, C., et al. (2011). Desulfovibrio piezophilus sp. nov., a piezophilic, sulfatereducing bacterium isolated from wood falls in the Mediterranean Sea. Int. J. Syst. Evol. Microbiol. 61, 2706-2711. doi: 10.1099/ijs.0.028670-0

Khelifi, N., Amin Ali, O., Roche, P., Grossi, V., Brochier-Armanet, C., Valette, O., et al. (2014). Anaerobic oxidation of long-chain n-alkanes by the hyperthermophilic sulfate-reducing archaeon. Archaeoglobus fulgidus. ISME J. 8, 3057-3060. doi: 10.1038/ismej.2014.58

Khelifi, N., Grossi, V., Hamdi, M., Dolla, A., Tholozan, J. L., Ollivier, B., et al. (2010). Anaerobic oxidation of fatty acids and alkenes by the hyperthermophilic sulfate-reducing archaeon Archaeoglobus fulgidus. Appl. Environ. Microbiol. 76, 3057-3060. doi: 10.1128/AEM.02810-09

Klenk, H. P., Clayton, R. A., Tomb, J. F., White, O., Nelson, K. E., Ketchum, K. A., et al. (1997). The complete genome sequence of the hyperthermophilic, sulphate-reducing archaeon Archaeoglobus fulgidus. Nature 390, 364-370. doi: $10.1038 / 37052$

Kusube, M., Kyaw, T. S., Tanikawa, K., Chastain, R. A., Hardy, K. M., Cameron, J., et al. (2017). Colwellia marinimaniae sp. nov., a hyperpiezophilic species isolated from an amphipod within the challenger deep. Mariana Trench. Int. J. Syst. Evol. Microbiol. 67, 824-831. doi: 10.1099/ijsem.0.001671

Lauro, F. M., and Bartlett, D. H. (2007). Prokaryotic lifestyles in deep sea habitats. Extremophiles 12, 15-25. doi: 10.1007/s00792-006-0059-5

Lauro, F. M., Chastain, R. A., Blankenship, L. E., Yayanos, A. A., and Bartlett, D. H. (2007). The unique 16S rRNA genes of piezophiles reflect both phylogeny and adaptation. Appl. Environ. Microbiol. 73, 838-845. doi: 10.1128/aem.01726-06

L'Haridon, S., Reysenbach, A.-L., Glenat, R., Prieur, D., and Jeanthon, C. (1995). Hot subterranean bioshphere in a continental oil reservoir. Nature 377, 223 224. doi: $10.1038 / 377223 \mathrm{a} 0$

Liu, R., Wang, L., Wei, Y., and Fang, J. (2018). The hadal biosphere: Recent insights and new directions. Deep-Sea Res. Part II 155, 11-18. doi: 10.1016/j.dsr2.2017. 04.015

Marteinsson, V. T., Birrien, J. L., Raguenes, G., da Costa, M. S., and Prieur, D. (1999). Isolation and characterization of Thermus thermophilus Gy1211 from a deep-sea hydrothermal vent. Extremophiles 3, 247-251. doi: 10.1007/ s007920050123

Marteinsson, V. T., Moulin, P., Birrien, J., Gambacorta, A., Vernet, M., and Prieur, D. (1997). Physiological responses to stress conditions and barophilic behavior of the hyperthermophilic vent archaeon pyrococcus physiological responses to stress conditions and barophilic behavior of the hyperthermophilic vent archaeon Pyrococcus abyssi. Appl. Environ. Microbiol. 63, 1230-1236. doi: 10. 1128/aem.63.4.1230-1236.1997

McNichol, J., Sylva, S. P., Thomas, F., Taylor, C. D., Sievert, S. M., and Seewald, J. S. (2016). Assessing microbial processes in deep-sea hydrothermal systems by incubation at in situ temperature and pressure. Deep-Sea Res. Part I 115, 221-232. doi: 10.1016/j.dsr.2016.06.011

Meulepas, R. J. W., Jagersma, C. G., Khadem, A. F., Stams, A. J. M., and Lens, P. N. L. (2010). Effect of methanogenic substrates on anaerobic oxidation of methane and sulfate reduction by an anaerobic methanotrophic enrichment. Appl. Microbiol. Biotechnol. 87, 1499-1506. doi: 10.1007/s00253-010-2597-0

Michels, P. C., Hei, D., and Clark, D. S. (1996). Enzymes and proteins from hyperthermophilic microorganisms. Adv. Protein Chem. 48, 341-376. doi: 10. 1016/S0065-3233(08)60366-6

Michoud, G., and Jebbar, M. (2016). High hydrostatic pressure adaptive strategies in an obligate piezophile Pyrococcus yayanosii. Scientific Reports 6, 1-10. doi: $10.1038 /$ srep27289

Miller, J. A. Y. F., Shah, N. N., Nelson, C. M., Ludlow, J. A. N. M., and Clark, D. S. (1988). Pressure and temperature effects on growth and methane production of the extreme thermophile Methanococcus jannaschii. Appl. Environ. Microbiol. 54, 3039-3042. doi: 10.1128/aem.54.12.3039-3042.1988 
Mori, K., Maruyama, A., Urabe, T., Suzuki, K. I., and Hanada, S. (2008). Archaeoglobus infectus sp. nov., a novel thermophilic, chemolithoheterotrophic archaeon isolated from a deep-sea rock collected at Suiyo Seamount. IzuBonin Arc, western Pacific Ocean. Int. J. Syst. Evol. Microbiol. 58, 810-816. doi: 10.1099/ijs.0.65422-0

Nakagawa, S., Takai, K., Inagaki, F., Chiba, H., Ishibashi, J. I., Kataoka, S., et al. (2005). Variability in microbial community and venting chemistry in a sediment-hosted backarc hydrothermal system: impacts of subseafloor phaseseparation. FEMS Microbiol. Ecol. 54, 141-155. doi: 10.1016/j.femsec.2005. 03.007

Nercessian, O., Reysenbach, A. L., Prieur, D., and Jeanthon, C. (2003). Archaeal diversity associated with in situ samplers deployed on hydrothermal vents on the East Pacific Rise. Environ. Microbiol. 5, 492-502. doi: 10.1046/j.1462-2920. 2003.00437.x

Nogi, Y., Kato, C., and Horikoshi, K. (1998). Moritella japonica sp. nov., a novel barophilic bacterium isolated from a Japan Trench sediment. J. Gen. Appl. Microbiol. 44, 289-295. doi: 10.2323/jgam.44.289

Oger, P. M., and Jebbar, M. (2010). The many ways of coping with pressure. Res. Microbiol. 161, 799-809. doi: 10.1016/j.resmic.2010.09.017

Park, C. B., and Clark, D. S. (2002). Rupture of the cell envelope by decompression of the deep-sea methanogen Methanococcus jannaschii. Appl. Environ. Microbiol. 68, 1458-1463. doi: 10.1128/AEM.68.3.1458

Peoples, L. M., and Bartlett, D. H. (2017). "Ecogenomics of deep-ocean microbial bathytypes," in Microbial Ecology of Extreme Environments, eds C. Chénard, and F. M. Lauro, (Berlin: Springer), 7-50. doi: 10.1007/978-3-319-5 $1686-8$

Picard, A., and Daniel, I. (2013). Pressure as an environmental parameter for microbial life - A review. Biophys. Chem. 183, 30-41. doi: 10.1016/j.bpc.2013. 06.019

Pinder, D. (2001). Offshore oil and gas: Global resource knowledge and technological change. Ocean Coast. Manag. 44, 579-600. doi: 10.1016/S09645691(01)00070-9

Prieur, D., and Marteinsson, V. T. (1998). Prokaryotes living under elevated hydrostatic pressure. Adv. Biochem. Eng. Biotechnol. 61, 23-35. doi: 10.1007/ bfb0102288

Rabus, R., Hansen, T. A., and Widdel, F. (2013). "Dissimilatory sulfate- and sulfur-reducing prokaryotes," in The Prokaryotes: Prokaryotic Physiology and Biochemistry, eds E. Rosenberg, et al. (Berlin: Springer), 309-404. doi: 10.1007/ 978-3-642-30141-4_70

Reveillaud, J., Reddington, E., McDermott, J., Algar, C., Meyer, J. L., Sylva, S., et al. (2016). Subseafloor microbial communities in hydrogen-rich vent fluids from hydrothermal systems along the Mid-Cayman Rise. Environ. Microbiol. 18, 1970-1987. doi: 10.1111/1462-2920.13173

Reysenbach, A. L., Holm, N. G., Hershberger, K., Prieur, D., and Jeanthon, C. (1998). In search of a subsurface biosphere at a slow-spreading ridge. Proc. Ocean Dril. Prog. 158, 355-360. doi: 10.2973/odp.proc.sr.158.229.1998

Reysenbach, A. L., Longnecker, K., and Kirshtein, J. (2000). Novel bacterial and archaeal lineages from an in situ growth chamber deployed at a mid-atlantic ridge hydrothermal vent. Appl. Environ. Microbiol. 66, 3798-3806. doi: 10.1128/ AEM.66.9.3798-3806.2000

Schrenk, M. O., Kelley, D. S., Delaney, J. R., and Baross, J. A. (2003). Incidence and diversity of microorganisms within the walls of an active deep-sea sulfide chimney. Appl. Environ. Microbiol. 69, 3580-3592. doi: 10.1128/AEM.69.6. 3580-3592.2003

Scoma, A., Garrido-Amador, P., Nielsen, S. D., Røy, H., and Kjeldsen, K. U. (2019). The polyextremophilic bacterium Clostridium paradoxum attains piezophilic traits by modulating its energy metabolism and cell membrane composition. Appl. Environ. Microbiol. 85, 1-14.

Steinsbu, B. O., Thorseth, I. H., Nakagawa, S., Inagaki, F., Lever, M. A., Engelen, B., et al. (2010). Archaeoglobus sulfaticallidus sp. nov., a thermophilic and facultatively lithoautotrophic sulfate-reducer isolated from black rust exposed to hot ridge flank crustal fluids. Int. J. Syst. Evol. Microbiol. 60, 2745-2752. doi: 10.1099/ijs.0.016105-0

Stetter, K. (1992). The genus Archaeoglobus. Prokaryotes 2, 707-711.

Stetter, K. O. (1988). Archaeoglobus fulgidus gen. nov., sp. nov.: a new taxon of extremely thermophilic archaebacteria. Syst. Appl. Microbiol. 10, 172-173. doi: 10.1016/S0723-2020(88)80032-8
Stetter, K. O., Fiala, G., Huber, G., Huber, R., and Segerer, A. (1990). Hyperthermophilic microorganisms. FEMS Microbiol. Lett. 75, 117-124. doi: 10.1016/0378-1097(90)90526-V

Stetter, K. O., Huber, R., Blöchl, E., Kurr, M., Eden, R. D., Fielder, M., et al. (1993). Hyperthermophilic archaea are thriving in deep North Sea and Alaskan oil reservoirs. Nature 365, 743-745. doi: 10.1038/365743a0

Stetter, K. O., Lauerer, G., Thomm, M., and Neuner, A. (1987). Isolation of extremely thermophilic sulfate reducers: evidence for a novel branch of archaebacteria. Science 236, 822-824. doi: 10.1126/science.236.4803.822

Straube, W. L., O’Brien, M., Davis, K., and Colwell, R. R. (1990). Ezymatic profiles of 11 barophilic bacteria under in situ conditions: Evidence for pressure modulation of phenotype. Appl. Environ. Microbiol. 56, 812-814. doi: 10.1128/ aem.56.3.812-814.1990

Sun, M. M., and Clark, D. S. (2001). "Pressure effects on activity and stability of hyperthermophilic enzymes," in Methods in Enzymology, eds J. Abelson, M. Simon, G. Verdine, and A. Pyle, (Cambridge, MA: Academic Press).

Takai, K., and Horikoshi, K. (1999). Genetic diversity of archaea in deep-sea hydrothermal vent environments. Genetics 152, 1285-1297. doi: 10.1016/s07232020(87)80053-x

Takai, K., Miyazaki, M., Hirayama, H., Nakagawa, S., Querellou, J., and Godfroy, A. (2009). Isolation and physiological characterization of two novel, piezophilic, thermophilic chemolithoautotrophs from a deep-sea hydrothermal vent chimney. Environ. Microbiol. 11, 1983-1997. doi: 10.1111/j.1462-2920. 2009.01921.x

Takai, K., Nakamura, K., Toki, T., Tsunogai, U., Miyazaki, M., Miyazaki, J., et al. (2008). Cell proliferation at $122^{\circ} \mathrm{C}$ and isotopically heavy $\mathrm{CH} 4$ production by a hyperthermophilic methanogen under high-pressure cultivation. Proc. Natl. Acad. Sci. U.S.A. 105, 10949-10954. doi: 10.1073/pnas.0712334105

Tasumi, E., Yanagawa, K., Miyazaki, J., and Takai, K. (2015). "In vitro high-pressure incubation and activity measurement of deep-sea methanogenic archaea," in Hydrocarbon and Lipid Microbiology Protocols, eds T. J. McGenity, et al. (Berlin: Springer), 51-64. doi: 10.1007/8623_2015_111

Teske, A., Hinrichs, K., Edgcomb, V., Gomez, A. D. V., Kysela, D., Sylva, S. P., et al. (2002). Microbial diversity of hydrothermal sediments in the guaymas basin: evidence for anaerobic methanotrophic communities. Am. Soc. Microbiol. 68, 1994-2007. doi: 10.1128/AEM.68.4.1994

Thauer, R. K., and Kunow, J. (1995). "Sulfate-Reducing Archaea," in SulfateReducing Bacteria, ed. L. L. Barton, (New York: Plenum Press), 33-45.

Vannier, P., Michoud, G., Oger, P., Marteinsson, V. P., and Jebbar, M. (2015). Genome expression of Thermococcus barophilus and Thermococcus kodakarensis in response to different hydrostatic pressure conditions. Res. Microbiol. 166, 717-725. doi: 10.1016/j.resmic.2015.07.006

Vezzi, A. (2005). Life at Depth: Photobacterium profundum genome sequence and expression analysis. Science 307, 1459-1461. doi: 10.1126/science.1103341

Welch, T. J., Farewell, A., Neidhardt, F. C., and Bartlett, D. H. (1993). Stress response of Escherichia coli to elevated hydrostatic pressure. J. Bacteriol. 175, 7170-7177. doi: 10.1128/jb.175.22.7170-7177.1993

Whitman, W. B., Coleman, D. C., and Wiebe, W. J. (1998). Prokaryotes: The unseen majority. Proc. Natl. Acad. Sci. U.S.A. 95, 6578-6583. doi: 10.1073/pnas.95.12. 6578

Williamson, A. J., Carlson, H. K., Kuehl, J. V., Huang, L. L., Iavarone, A. T., Deutschbauer, A., et al. (2018). Dissimilatory sulfate reduction under high pressure by Desulfovibrio alaskensis G20. Front. Microbiol. 9:1465. doi: 10.3389/ fmicb.2018.01465

Yayanos, A. A. (1995). Microbiology to 10,500 meters in the deep sea. Annu. Rev. Microbiol. 49, 777-805. doi: 10.1146/annurev.micro.49.1.777

Yayanos, A. A. (2001). 30 Deep-sea piezophilic bacteria. Methods Microbiol. 30, 615-637. doi: 10.1016/s0580-9517(01)30065-x

Yayanos, A. A., Dietz, A. S., and Boxtel, V. (1982). Dependance of reproduction rate on pressure as a hallmark of deep-sea bacteria. Appl. Environ. Microbiol. 44, 1356-1361. doi: 10.1128/aem.44.6.1356-1361.1982

Yu, L., Zhou, Z., Wei, S., Xu, X., Wang, Q., Xu, G., et al. (2019). Marinomonas piezotolerans sp. nov., isolated from deep-sea sediment of the Yap Trench, Pacific Ocean. Int. J. Syst. Evol. Microbiol. 69, 739-744. doi: 10.1099/ijsem.0. 003227

Zellner, G., Stackebrandt, E., Kneifel, H., Messner, P., Sleytr, U. B., de Macario, E. C., et al. (1989). Isolation and characterization of a thermophilic, sulfate reducing 
archaebacterium. Archaeoglobus fulgidus Strain Z. Syst. Appl. Microbiol. 11, 151-160. doi: 10.1016/S0723-2020(89)80055-4

Zeng, X., Birrien, J.-L., Fouquet, Y., Cherkashov, G., Jebbar, M., Querellou, J., et al. (2009). Pyrococcus $\mathrm{CH} 1$, an obligate piezophilic hyperthermophile: extending the upper pressure-temperature limits for life. ISME J. 3, 873-876. doi: 10.1038/ ismej.2009.21

Zhang, Y., Li, X., Xiao, X., and Bartlett, D. H. (2015). Current developments in marine microbiology: High-pressure biotechnology and the genetic engineering of piezophiles. Curr. Opin. Biotechnol 33, 157-164. doi: 10.1016/j.copbio.2015. 02.013

Zhao, W., Zeng, X., and Xiao, X. (2015). Thermococcus eurythermalis sp. nov., a conditional piezophilic, hyperthermophilic archaeon with a wide temperature range for growth, isolated from an oil-immersed chimney in the Guaymas Basin. Int. J. Syst. Evol. Microbiol. 65, 30-35. doi: 10.1099/ijs.0.067942-0
Zobell, C. E., and Oppenheimer, C. H. (1950). Some effects of hydrostatic pressure on the multiplication and morphology of marine bacteria. J. Bacteriol. 60, 771-781. doi: $10.1128 / \mathrm{jb}$.60.6.771-781.1950

Conflict of Interest: The authors declare that the research was conducted in the absence of any commercial or financial relationships that could be construed as a potential conflict of interest.

Copyright $\odot 2020$ Oliver, Cario and Rogers. This is an open-access article distributed under the terms of the Creative Commons Attribution License (CC BY). The use, distribution or reproduction in other forums is permitted, provided the original author(s) and the copyright owner(s) are credited and that the original publication in this journal is cited, in accordance with accepted academic practice. No use, distribution or reproduction is permitted which does not comply with these terms. 